Article

\title{
Functionalization of the Chalcone Scaffold for the Discovery of Novel Lead Compounds Targeting Fungal Infections
}

\author{
Francesca Bonvicini ${ }^{1}{ }^{\circledR}$, Giovanna A. Gentilomi ${ }^{1,2}{ }^{2}$, Francesca Bressan ${ }^{3}$, Silvia Gobbi ${ }^{3}{ }^{\circledR}$, \\ Angela Rampa ${ }^{3}{ }^{-}$, Alessandra Bisi ${ }^{3}\left(\mathbb{C}\right.$ and Federica Belluti ${ }^{3, *}$ \\ 1 Department of Pharmacy and Biotechnology, Alma Mater Studiorum-University of Bologna, \\ Via Massarenti 9, 40138 Bologna, Italy; francesca.bonvicini4@unibo.it (F.B.); \\ giovanna.gentilomi@unibo.it (G.A.G.) \\ 2 Unit of Microbiology, Alma Mater Studiorum-University of Bologna, S. Orsola-Malpighi Hospital, \\ Via Massarenti 9, 40138 Bologna, Italy \\ 3 Department of Pharmacy and Biotechnology, Alma Mater Studiorum-University of Bologna, \\ Via Belmeloro 6, 40126 Bologna, Italy; francesca.bressan@studio.unibo.it (F.B.); silvia.gobbi@unibo.it (S.G.); \\ angela.rampa@unibo.it (A.R.); alessandra.bisi@unibo.it (A.B.) \\ * Correspondence: federica.belluti@unibo.it; Tel.: +39-0512099732
}

Received: 28 November 2018; Accepted: 16 January 2019; Published: 21 January 2019

\begin{abstract}
The occurrence of invasive fungal infections represents a substantial threat to human health that is particularly serious in immunocompromised patients. The limited number of antifungal agents, devoid of unwanted toxic effects, has resulted in an increased demand for new drugs. Herein, the chalcone framework was functionalized to develop new antifungal agents able to interfere with cell growth and with the infection process. Thus, a small library of chalcone-based analogues was evaluated in vitro against $C$. albicans ATCC 10231 and a number of compounds strongly inhibited yeast growth at non-cytotoxic concentrations. Among these, $\mathbf{5}$ and $\mathbf{7}$ interfered with the expression of two key virulence factors in C. albicans pathogenesis, namely, hyphae and biofilm formation, while 28 emerged as a potent and broad spectrum antifungal agent, enabling the inhibition of the tested Candida spp. and non-Candida species. Indeed, these compounds combine two modes of action by selectively interfering with growth and, as an added value, weakening microbial virulence. Overall, these compounds could be regarded as promising antifungal candidates worthy of deeper investigation. They also provide a chemical platform through which to perform an optimization process, addressed at improving potency and correcting liabilities.
\end{abstract}

Keywords: anti-virulence agents; biofilm; Candida albicans chalcone scaffold; clinically relevant yeasts; fluorine atom; yeast-to-hyphae transition

\section{Introduction}

Life-threatening invasive fungal infections (IFIs) have been widely recognized as the "hidden killers" of immunocompromised individuals such as patients subjected to organ transplantation and those affected by cancer or AIDS [1,2]. Recently, IFIs have become a severe health problem due to their association with high incidence and mortality [3]. Candidiasis is the main etiologic factor triggering IFIs, with a mortality rate ranging from $46 \%$ to $75 \%$ for Candida albicans, and from $20 \%$ to $70 \%$ for Cryptococcus neoformans [2].

Candida spp. are members of the commensal human microflora in anatomically distinct sites (oral, gastrointestinal, and genitourinary tracts) but, as stated above, under an extensive variety of circumstances (specific immune defects, mucosal or cutaneous barrier disruption, ageing, diabetes, 
AIDS) they can be responsible for a wide spectrum of serious clinical symptoms. The pathogenicity of the Candida spp. is attributed to critical virulence factors, such as yeast-hyphal transition, adherence to surfaces, production of proteolytic enzymes, and the formation of biofilm, a structure consisting of multicellular microbial communities embedded in a self-produced polymeric matrix [4]. One of the main consequences of the biofilm mode of growth is the enhanced resistance to host defense mechanisms and antifungal drugs, which is why biofilm-associated infections are frequently refractory to conventional therapy. Even if the incidence of resistance among human fungal pathogens is low to moderate compared to antibiotic resistance among bacterial pathogens, the rising problem of multi-drug resistance is becoming a major concern for clinicians. Moreover, epidemiological data reveal that, although $C$. albicans remains the most common species isolated in superficial and invasive fungal infections, the distribution is changing and other yeasts, including opportunistic and ubiquitous saprophytic fungus, are increasingly recovered in immunocompromised hosts, particularly those with central venous catheters or other indwelling devices $[5,6]$.

At present, only a limited number of antifungal agents, namely fluconazole (FLC, Figure 1), voriconazole, and itraconazole, most of which are characterized by an azole function, are in preclinical or clinical studies or available for IFIs treatment [7]. Several limitations such as restricted spectrum of action, toxicity, low efficacy, emergence of resistance, and critical pharmacodynamic and pharmacokinetic profiles, have been recognized to plague this class of therapeutics [8]. On the other hand, Amphotericin B, a very effective and broad-spectrum therapeutic agent for fungal infections, has also shown several side effects [9]. In this scenario, the discovery of novel compounds active against human pathogenic yeasts is an urgent need. Ideally, an antifungal agent should be broad-spectrum, effective against both morphotypes of the yeast (blastospore and hyphae) and biofilms, but also able to reduce the expression of virulence factors. Valuable in this respect are natural products (NPs) and plant-derived secondary metabolites, which exert antimicrobial activity without conferring resistance [10]. NPs, small molecules synthesized by the plant kingdom, define evolutionarily chosen "privileged structures" [11] since they have evolved in a natural selection process to achieve optimal interactions with biological macromolecules. Thus, NPs-inspired compound collections may allow the identification of new molecular templates, suitable for the design of new effective antimicrobial agents. The pharmaceutical industry has extensively relied on NP classes for the discovery of antimicrobics, including polyenes and echinocandins [12]

In this respect, chalcones (1,3-diaryl-2-propen-1-ones) are a prominent class of secondary metabolites and precursors of flavonoids endowed with a wide range of activities, including anti-oxidant, anti-metastatic, anti-inflammatory, and antimicrobial, as extensively reported in many reviews [13]. The molecular basis of chalcones pleiotropic behavior, involving the modulation of multiple biochemical pathways, are likely to be ascribed to their sulfhydryl reactive $\alpha, \beta$-unsaturated carbonyl function, a motif largely found in a variety of bioactive NPs. Indeed, the chalcone scaffold demonstrated its suitability to serve as a chemical platform to obtain, upon properly addressed modifications, small compound libraries that may allow performing structure-activity relationship (SAR) studies [14,15].

Licochalcone A (Figure 1 and Table 1), isolated from the roots of the Chinese plant Glycyrrhiza glabra, has been shown to inhibit the in vitro growth of different strains of C. albicans, both sensitive and resistant to FLC, with minimum inhibitory concentration (MIC) values in the 62.5-150 $\mu \mathrm{M}$ range. Moreover, at $650 \mu \mathrm{M}$ concentration, it reduces yeast viability within a mature biofilm [16].

\section{Results}

\subsection{Design Strategy}

In an effort to uncover new starting points for antifungal drug discovery, an in-house small library of chalcone-based analogues (Table 1) was screened against C. albicans, as a continuation of our exploration of this privileged scaffold as suitable template for developing anti-infective agents. 
Indeed, some members of the library have been previously tested versus Leishmania donovani [17], and a number of compounds endowed with encouraging in vitro activity were identified. To gain insight into the key features for eliciting the antifungal effect, the chemical variability of the chalcones regarded the substitution patterns of the A- and B-rings, as depicted in Figure 1, resulting in Series I, II, and III. Concerning the A-ring: a) Series I was characterized by a 2,5-substutution pattern; in particular, a hydroxyl group was introduced into the 2-position, while a halogen atom such as chlorine or fluorine occupies the 5-position to give Series Ia and Ib, respectively. b) Series II was characterized by a 2,4-disubstitution pattern; in details, position-2 was decorated with hydroxy, methoxy, or propargyloxy functions, while various alkoxy functions were appended into the 4-position. c) Series III contained an alkoxy function into the 4-position. Regarding the B-ring, the following substituents were frequently introduced: 2,4-diCl, 4-dimethylamino, 4-nitro, 4-fluorine, 3- and 4-pyridyl. A number of tested compounds were characterized by a pyridine heterocyclic nucleus $(12,13,16,20,21,24,25,32,33$, $36,37)$ as a privileged moiety present in several anti-infective agents [18], and by a F-phenyl ring (2-5, $7,8,10,18,22,28-31)$. This small and highly electronegative atom confers special chemical reactivity to the molecule by imparting several favorable properties including improved metabolic stability, selectivity, and efficacy in binding [19]. Taking advantage of these important issues, we successfully exploited this substituent for drug discovery purposes [20,21].<smiles>OC(Cn1cncn1)(Cn1cncn1)c1cc(F)cc(F)c1</smiles>

Fluconazole<smiles>C=CC(C)(C)c1cc(/C=C/C(=O)c2ccc(O)cc2)c(OC)cc1O</smiles>

licochalcone A

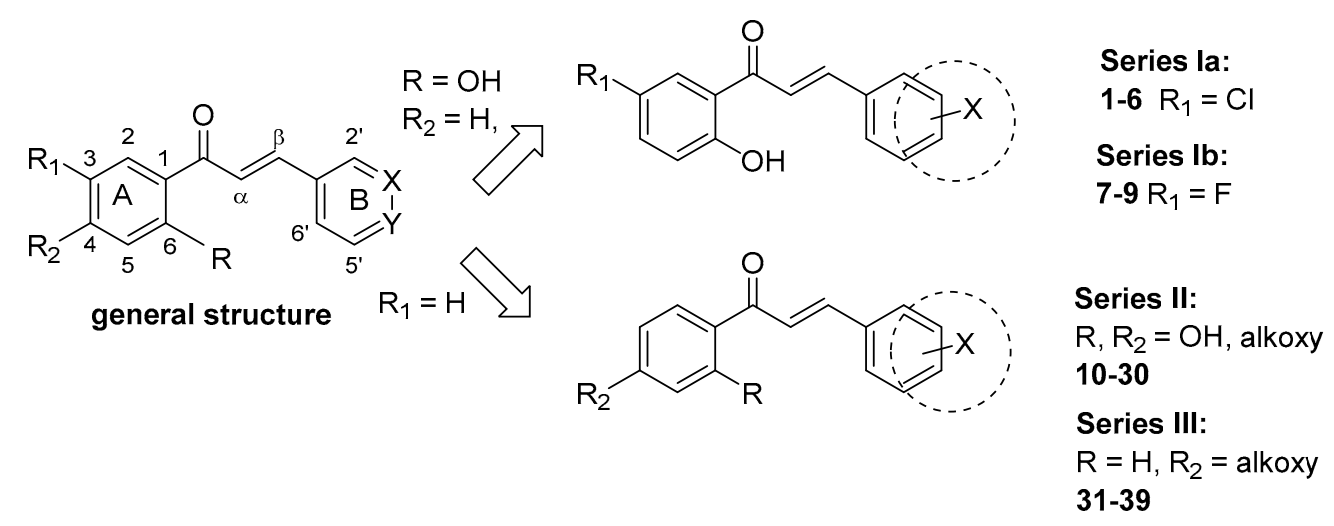

Figure 1. Structure of fluconazole, licochalcone A, and general structures of the tested chalcones.

\subsection{Chemistry}

The final compounds were obtained as described in Scheme 1. The Williamson etherification of 2,4-dihydroxyacetophenone with the appropriate alkyl bromide in the presence of $\mathrm{K}_{2} \mathrm{CO}_{3}$ allowed obtaining the acetophenone-based intermediates $(41-45,46,47)$. In particular, treatment of 2,4-dihydroxyacetophenone with 3,3-dimethylallylbromide, propargylbromide or 1-Br,2-Cl-ethane allowed obtaining 41, 42 [17] and 43, respectively [21] that were subsequently alkylated with methyliodide to give 44, 45 [17], and 46. Alkylation of 42 with propargylbromide gave 47 [17], which was then reacted with phenylpiperazine to achieve intermediate 48 . Acetophenone 49 was obtained through a Huisgen cycloaddition (click chemistry) reaction between the alkyne 45 and 2-azidoethan-1-ol in the presence of $\mathrm{CuSO}_{4}$ and Na-ascorbate as catalysts. An aldol condensation (Claisen-Schmidt) procedure allowed obtaining the chalcone-based analogues. In detail, three different 
reaction conditions were employed: $50 \%$ aqueous $\mathrm{NaOH}$ solution; piperidine/acetic acid; $\mathrm{Ba}(\mathrm{OH})_{2}$ reported as Routes A, B, and C, respectively.
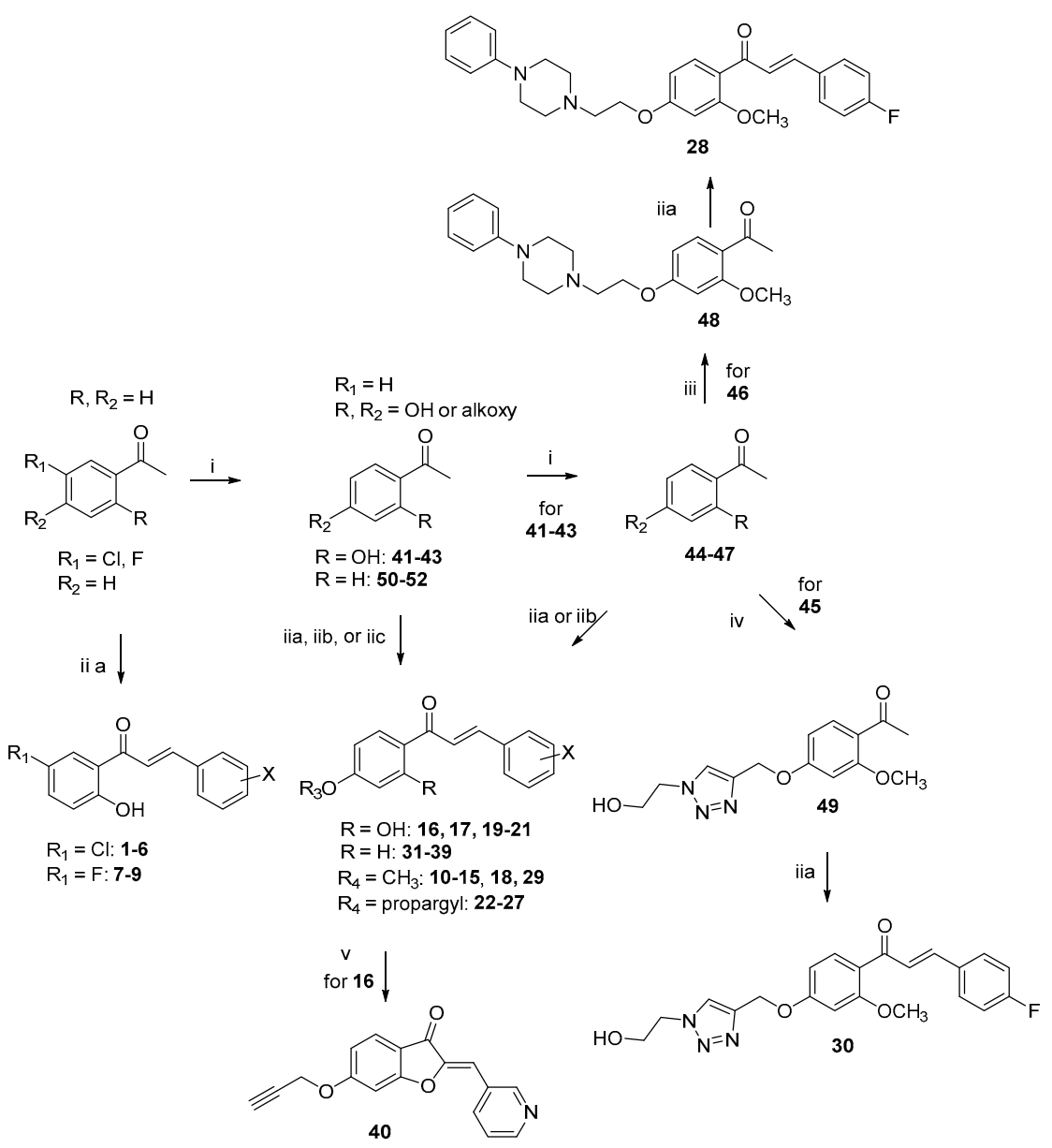

Scheme 1. Synthetic route for obtaining analogues 1-40. Reagent and conditions: i) selected alkyl halide, $\mathrm{K}_{2} \mathrm{CO}_{2}$, acetone, reflux; ii) selected aldehyde, $\mathrm{EOH}$, a) Route $\mathrm{A}: \mathrm{KOH} / \mathrm{H}_{2} \mathrm{O} 50 \%$, rt; b) Route B: piperidine/ $\mathrm{AcOH}$, reflux, c) Route $\mathrm{C}: \mathrm{Ba}(\mathrm{OH})_{2}$, rt; iii) phenylpiperazine, TEA, THF, rt; iv) 2-azidoethan-1-ol, $\mathrm{CuSO}_{4}$, Na-ascorbate, DMSO; v) $\mathrm{NaOH}, \mathrm{H}_{2} \mathrm{O}_{2}$, EtOH, $0{ }^{\circ} \mathrm{C}$-rt.

\subsection{Biological Evaluation}

A screening pipeline was developed to assess the therapeutic potential of the synthesized molecules (1-40). The antifungal activity was firstly investigated as ability to affect in vitro C. albicans growth (control strain, ATCC 10231). A set of compounds were then selected for their ability to show an inhibitory activity superior to $50 \%$ at $100 \mu \mathrm{M}$, and for these the $\mathrm{IC}_{50}$ were determined. Afterwards, these derivatives were subjected to dose-effect safety experiments in mammalian epithelial cells (Vero, ATCC CCL-81). Chalcones having a positive selectivity index (SI), calculated as $\mathrm{CC}_{50} / \mathrm{IC}_{50}$ ratio, were further investigated to measure their effect on different stages of fungal virulence, namely yeast-to-hyphae morphological transition, filaments invasion, and biofilm formation. Moreover, these active compounds were also assayed on a panel of ten pathogenic yeasts obtained from clinical specimens, including Candida spp. and non-Candida species, in order to fully characterize their antifungal potential.

\subsubsection{Specific Inhibition of Candida albicans Growth}

The tested analogues 1-40 were firstly evaluated against C. albicans ATCC 10231 at $100 \mu \mathrm{M}$. The commercially available antifungal FLC was used as running control to check the quality of 
the tests (growth/inhibition of the strains as defined by EUCAST guidelines) [22]. For compounds demonstrating activity against fungal growth superior to $50 \%, \mathrm{IC}_{50}$ values were determined from a six-point dose-response curve, obtained in the concentration range 200-6.25 $\mu \mathrm{M}$. From the data reported in Table 1 (expressed both in $\mu \mathrm{M}$ and in $\mu \mathrm{g} / \mathrm{mL}$ ) some general structure-activity relationships (SAR) can be drawn. Positively, sixteen out of the tested forty small molecules successfully inhibited C. albicans growth.

Series Ia provided a number of active derivatives. In detail, the simple phenyl ring (as in compound 1), along with the 3-F-, 4-F-, and 3,5-di-F-phenyl substitution (compounds 3, 4, and 5, respectively) resulted in potent inhibition of cell growth, with $\mathrm{IC}_{50}$ values ranging from $48.9 \mu \mathrm{M}$ to $57.7 \mu \mathrm{M}$. On the contrary, the 2-F-phenyl function negatively affected activity (compound 2, $35.8 \%$ of inhibition), while the 4-dimethylaminophenyl moiety (6) resulted in an inactive compound. Replacement of the $5-\mathrm{Cl}$ of the A-ring with a fluorine atom (Series $\mathrm{Ib}$ ) seemed not to affect the activity of derivative 7, which maintained a good antifungal effect $\left(\mathrm{IC}_{50}=53 \mu \mathrm{M}\right)$, comparable to that of 3 . Surprisingly, a loss of potency, with respect to 4 , was observed for the 4-F substituted 8 , while increased activity was obtained with the 4-dimethylamino (9, 38.5\% of inhibition).

The effect elicited by the pyridine-based B-ring in conferring antifungal activity was extensively investigated. Among the sub-set with a 4-propargyloxy side chain (compounds 12, 13, 16, 24, and 25), promising results were observed ( $\mathrm{IC}_{50}$ values ranging from 8.1 to $43.8 \mu \mathrm{M}$ ). In particular, 13, characterized by the methoxy group in the 2-position and the 4-pyridyl function, proved to be one of the most active within the series $\left(\mathrm{IC}_{50}=8.1 \mu \mathrm{M}\right)$. The 3-pyridyl analogue 12, structurally related to 13, showed decreased inhibitory potency $\left(\mathrm{IC}_{50}=30.7 \mu \mathrm{M}\right)$, while compound 16 , the demethylated analogue of $\mathbf{1 2}$, was as active as $\mathbf{1 3}\left(\mathrm{IC}_{50}\right.$ value of $\left.10.8 \mu \mathrm{M}\right)$. In the same way, the 2,4-di-propargyloxylated 24 and 25 (4- and 3- pyridine, respectively), showed inhibitory values of $26.3 \mu \mathrm{M}$ and $43.8 \mu \mathrm{M}$. Also, analogues 20 and 21, characterized by the 2-hydroxy and 4-(3,3-dimethylalliloxy) moieties, turned out to remarkably inhibit $C$. albicans, as potencies in the single-digit micromolar range were observed. The pyridine-based chalcones $32,33,36$, and 37 , in which the 2-substituent was removed (Series III), proved to be devoid of any effect.

All chalcones bearing the 4-dimethylaminophenyl $(\mathbf{1 5}, \mathbf{1 7}, \mathbf{2 7}, \mathbf{3 5}, \mathbf{3 9})$ and the 2,4-di-Cl-phenyl (11, $19,23)$ functions as B-ring were inactive (Series II). Regarding the 4-nitro substitution of the B-ring, good inhibitory effects were observed ( $\mathbf{1 4}$ and $\mathbf{2 6}, \mathrm{IC}_{50}=39.2 \mu \mathrm{M}$ and $36.8 \mu \mathrm{M}$, respectively). Again, the corresponding nitro-analogues of Series III (34 and 38) turned out to be inactive.

In addition, the effect elicited by the presence of the fluorine atom on the B-ring was investigated through a number of compounds $(\mathbf{1 0}, \mathbf{1 8}, \mathbf{2 2}, \mathbf{2 8}-\mathbf{3 1})$ characterized by different substituents on the A-ring. In this regard, chalcones with simple alkoxylated functions showed poor activity: compound $\mathbf{2 2}$ was inactive and analogues $\mathbf{1 0}$ and $\mathbf{1 8}$ inhibited the C. albicans growth with percentages of 23.3 and 34.1, respectively. Interestingly, the decoration of the A-ring with hydrophilic functions (compounds 28-31) showed different behavior. The ethoxyphenylpiperazine (28) conferred a good antifungal effect: $\mathrm{IC}_{50}$ value of $55.9 \mu \mathrm{M}$. On the contrary, 30, characterized by a 2-hydroxyethyl-1H-1,2,3-triazole, proved to be inactive. In addition, poor inhibition was noticed for 29 with a more hydrophilic phenol group. Conversely, 31, with a 4-hydroxyethoxy side chain, displayed a very good inhibitory effect $\left(\mathrm{IC}_{50}=12.0 \mu \mathrm{M}\right)$. Finally, the cyclization of the chalcone scaffold into the constrained 2-arylidenebenzofuran-3-one (aurone), still maintaining the unsaturated carbonyl framework, was performed for $\mathbf{1 3}$, to obtain derivative $\mathbf{4 0}$. This last modification caused a loss in activity, leading us to assume that an optimal inhibitory effect is governed by the presence of the propen-1-one flexible linker between aryl A- and B-rings. 
Table 1. Antifungal effect of chalcone-based analogues 1-40 against C. albicans control strain.

\begin{tabular}{|c|c|c|c|c|}
\hline Compound & Structure & $\begin{array}{c}\text { Inhibition (\%) } \\
\text { [at } 100 \mu \mathrm{M}]\end{array}$ & $\mathrm{IC}_{50}[\mu \mathrm{M}]^{\mathrm{a}, \mathrm{b}}$ & $\mathrm{IC}_{50}[\mu \mathrm{g} / \mathrm{mL}]^{\mathrm{a}, \mathrm{b}}$ \\
\hline 1 & & $65.2 \pm 3.9$ & $52.8[44.6-62.6]$ & 13.7 [11.5-16.2] \\
\hline 2 & & $35.8 \pm 1.1$ & n.d. & n.d. \\
\hline 3 & & $64.8 \pm 1.5$ & $57.7[47.1-70.8]$ & 16.0 [13.0-19.6] \\
\hline 4 & & $65.6 \pm 3.3$ & $48.9[41.9-57.0]$ & 13.5 [11.6-15.8] \\
\hline 5 & & $62.0 \pm 1.5$ & $51.3[41.3-63.8]$ & $15.1[12.2-18.8]$ \\
\hline 6 & & $<1$ & n.d. & n.d. \\
\hline 7 & & $69.0 \pm 12.4$ & $53.0[43.8-64.0]$ & 13.8 [11.4-16.7] \\
\hline 8 & & $<1$ & n.d. & n.d. \\
\hline 9 & & $38.5 \pm 2.9$ & n.d. & n.d. \\
\hline $10^{c}$ & & $23.3 \pm 9.6$ & n.d. & n.d. \\
\hline 11 & & $9.8 \pm 6.7$ & n.d. & n.d. \\
\hline $12^{c}$ & & $>99$ & $30.7[27.0-35.0]$ & 9.0 [7.9-10.3]. \\
\hline $13^{c}$ & & $>99$ & 8.1 [6.8-9.6] & $2.4[2.0-2.8]$ \\
\hline $14^{c}$ & & $63.6 \pm 6.8$ & $39.2[26.8-57.4]$ & 11.5 [7.9-16.8] \\
\hline
\end{tabular}


Table 1. Cont.

\begin{tabular}{|c|c|c|c|c|}
\hline Compound & Structure & $\begin{array}{c}\text { Inhibition (\%) } \\
\text { [at } 100 \mu \mathrm{M}]\end{array}$ & $\mathrm{IC}_{50}[\mu \mathrm{M}]^{\mathrm{a}, \mathrm{b}}$ & $\mathrm{IC}_{50}[\mu \mathrm{g} / \mathrm{mL}]^{\mathrm{a}, \mathrm{b}}$ \\
\hline 15 & & $<1$ & n.d. & n.d. \\
\hline $16^{\mathrm{c}}$ & & $91.9 \pm 8.2$ & 10.8 [9.3-12.5] & $3.2[2.7-3.7]$ \\
\hline 17 & & $11.0 \pm 3.9$ & n.d. & n.d. \\
\hline $18^{c}$ & & $34.1 \pm 7.5$ & n.d. & n.d. \\
\hline 19 & & $5.9 \pm 5.7$ & n.d. & n.d. \\
\hline $20^{c}$ & & $81.5 \pm 4.7$ & 16.8 [13.6-20.6] & $4.9[4.0-6.0]$ \\
\hline $21^{c}$ & & $96.5 \pm 1.4$ & $12.6[10.6-15.1]$ & $3.7[3.1-4.4]$ \\
\hline $22^{c}$ & & $<1$ & n.d. & n.d. \\
\hline 23 & & $4.6 \pm 13.8$ & n.d. & n.d. \\
\hline $24^{c}$ & & $72.0 \pm 9.8$ & $43.8[30.6-62.7]$ & $12.8[9.0-18.4]$ \\
\hline $25^{c}$ & & $81.3 \pm 17.0$ & $26.3[19.6-35.4]$ & 7.7 [5.7-10.4] \\
\hline $26^{c}$ & & $63.9 \pm 3.4$ & 36.8 [29.2-46.3] & 10.8 [8.6-13.6] \\
\hline 27 & & $<1$ & n.d. & n.d. \\
\hline 28 & & $99.1 \pm 0.7$ & 55.9 [50.9-61.3] & $27.7[25.2-30.4]$ \\
\hline
\end{tabular}


Table 1. Cont.

\begin{tabular}{|c|c|c|c|c|}
\hline Compound & Structure & $\begin{array}{c}\text { Inhibition (\%) } \\
\text { [at } 100 \mu \mathrm{M}]\end{array}$ & $\mathrm{IC}_{50}[\mu \mathrm{M}]^{\mathrm{a}, \mathrm{b}}$ & $\mathrm{IC}_{50}[\mu \mathrm{g} / \mathrm{mL}]^{\mathrm{a}, \mathrm{b}}$ \\
\hline 29 & & $17.8 \pm 4.1$ & n.d. & n.d. \\
\hline 30 & & $9.5 \pm 4.8$ & n.d. & n.d. \\
\hline 31 & & $97.3 \pm 0.5$ & $12.0[9.3-15.6]$ & $3.5[2.7-4.6]$ \\
\hline 32 & & $<1$ & n.d. & n.d. \\
\hline 33 & & $<1$ & n.d. & n.d. \\
\hline 34 & & $37.9 \pm 5.2$ & n.d. & n.d. \\
\hline 35 & & $13.9 \pm 3.6$ & n.d. & n.d. \\
\hline 36 & & $<1$ & n.d. & n.d. \\
\hline 37 & & $<1$ & n.d. & n.d. \\
\hline 38 & & $46.3 \pm 3.7$ & n.d. & n.d. \\
\hline 39 & & $<1$ & n.d. & n.d. \\
\hline 40 & & $<1$ & n.d. & n.d. \\
\hline $\begin{array}{l}\text { Licochalcone }^{\mathrm{d}} \\
\text { FLC }\end{array}$ & & n.d. & $\begin{array}{c}62.5-150 \\
0.25[0.18-0.33]\end{array}$ & $\begin{array}{c}18.3-44.0 \\
0.07[0.05-0.1]\end{array}$ \\
\hline
\end{tabular}

${ }^{\mathrm{a}} \mathrm{IC}_{50}$ is defined as the concentration giving rise to an inhibition of growth of $50 \%$ compared to the drug-free control.

b Data are reported as mean values and 95\% confidence interval. c See [17]. d See [16], FLC, fluoconazole; n.d., not determined.

\subsubsection{Cytotoxicity Assay}

Fungi and mammalian cells share analogous cellular and biochemical pathways; thus, an ideal antifungal agent should be devoid of unwanted side effects. In light of the liabilities of the chalcone 
scaffold [23], our sixteen best-performing compounds were tested on mammalian epithelial cells (Vero) treated for $72 \mathrm{~h}$ with different concentrations of chalcones (200-6.25 $\mu \mathrm{M}$ range), and cell viability was evaluated. Table 2 reports $\mathrm{CC}_{50}$ values in both $\mu \mathrm{M}$ and in $\mu \mathrm{g} / \mathrm{mL}$. This cytotoxicity assay allows us to establish whether the observed effect is associated with a specific ability to affect fungal growth and not purely linked to a general toxic effect.

Table 2. Cytotoxicity of selected chalcone-based analogues against Vero cells $\left(\mathrm{CC}_{50}\right.$ values are expressed in $\mu \mathrm{M}$ and $\mu \mathrm{g} / \mathrm{mL})$.

\begin{tabular}{ccc}
\hline Compound & $\mathbf{C C}_{\mathbf{5 0}}[\mu \mathrm{M}]^{\mathrm{a}, \mathrm{b}}$ & $\mathrm{CC}_{\mathbf{5 0}}[\mu \mathrm{g} / \mathrm{mL}]^{\mathrm{a}, \mathrm{b}}$ \\
\hline $\mathbf{1}$ & $174.1[157.0-193.1]$ & $45[40.6-50.0]$ \\
$\mathbf{3}$ & $151.8[131.7-175.0]$ & $42.0[36.4-48.4]$ \\
$\mathbf{4}$ & $>200$ & $>55.3$ \\
$\mathbf{5}$ & $>200$ & $>58.9$ \\
$\mathbf{7}$ & $181.7[126.3-261.4]$ & $47.3[32.9-68.0]$ \\
$\mathbf{1 2}$ & $13.6[12.7-14.6]$ & $4.0[3.7-4.3]$ \\
$\mathbf{1 3}$ & $7.3[6.2-8.7]$ & $2.1[1.8-2.5]$ \\
$\mathbf{1 4}$ & $>200$ & $>58.6$ \\
$\mathbf{1 6}$ & $17.8[15.8-20.1]$ & $5.2[4.6-5.9]$ \\
$\mathbf{2 0}$ & $54.3[50.3-58.5]$ & $15.9[14.8-17.2]$ \\
$\mathbf{2 1}$ & $14.8[13.7-16.0]$ & $4.3[4.0-4.7]$ \\
$\mathbf{2 4}$ & $13.0[11.4-14.8]$ & $3.8[3.3-4.3]$ \\
$\mathbf{2 5}$ & $9.1[8.6-9.8]$ & $2.7[2.5-2.9]$ \\
$\mathbf{2 6}$ & $5.1[4.7-5.5]$ & $1.5[1.4-1.6]$ \\
$\mathbf{2 8}$ & $>200$ & $>99.2$ \\
$\mathbf{3 1}$ & $8.3[7.1-9.6]$ & $2.4[2.1-2.8]$ \\
\hline
\end{tabular}

${ }^{a} \mathrm{CC}_{50}$ is defined as the concentration giving rise to an inhibition of growth of $50 \%$ compared to untreated Vero cells.

${ }^{\mathrm{b}}$ Data are reported as mean values and $95 \%$ confidence interval.

In particular, compounds $4,5,14$, and 28 did not display any toxicity, as they did not interfere at all with Vero metabolism, even at the highest concentration of $200 \mu \mathrm{M}$. In addition, compounds 1, 3, and 7, showing triple-digit micromolar $\mathrm{CC}_{50}$ values $(174.1 \mu \mathrm{M}, 151.8 \mu \mathrm{M}$, and $181.7 \mu \mathrm{M}$, respectively), only slightly affected eukaryotic cell growth, and could therefore be considered non-toxic.

Analogue 20 was moderately toxic $\left(\mathrm{CC}_{50}=54.3 \mu \mathrm{M}\right)$; nevertheless, its good antifungal effect $\left(\mathrm{IC}_{50}=16.8 \mu \mathrm{M}\right)$ somewhat counterbalances this drawback and, generally, for this compound, an acceptable host/fungi selectivity profile could be assumed. Altogether, these results point to 20 as a promising compound worth modifying to decrease the toxicity.

Conversely, compounds $13,16,21,24-26$, and 31 were associated with a certain degree of toxicity since they showed $\mathrm{CC}_{50}$ values in the micromolar range that were not significantly different from the $\mathrm{IC}_{50}$ values on $C$. albicans. Therefore, their activity on yeast growth could be considered a generic cytotoxic effect, thus precluding any further investigation.

Overall, considering that all compounds belonging to Series I were non-toxic, its key chemical features, namely the 2-hydroxy-5-halo substitution pattern of the A-ring, coupled with fluorine decoration of the B-ring, are expected to lead to effective antifungal agents.

Moreover, analogues 28 and 31, both bearing a 4-F aryl ring, showed the opposite behavior. The measured toxic effects could be ascribed to the decoration pattern of the A-ring. This trend is also found for the couple 14/31 endowed with a 4-nitrophelyl moiety and differing from the substituent appended at the 2-position (methoxy/propargiloxy).

Since analogues 1, 3-5, 7, 14, and 28 displayed a good safety profile, they were considered for additional evaluations regarding their antimicrobial profile. Their $\mathrm{IC}_{50}$ values are comparable to those measured for the lichochalcone A over different strains of C. albicans in a recently published paper [16], again confirming chalcone as a privileged scaffold, suitable for the development of antifungal agents.

The above in vitro toxicity evaluation demonstrated some liabilities of the chalcone scaffold and helped us to gain insight into the chemical features affecting or modulating toxic effects. Of note, the pyridine as B-ring undoubtedly represents an issue that needs to be addressed in designing the next generation of derivatives. 


\subsubsection{Inhibition of Candida spp. and non-Candida Yeasts}

After we assessed the selective inhibition of chalcones 1, 3-5, 7, 14, and 28 over C. albicans ATCC 10231, we further assayed them towards seven clinical isolates of Candida spp. and three non-Candida yeasts (Tables 3 and 4, respectively). The C. albicans strain recovered from a clinical specimen displayed a susceptibility profile similar to that defined for the control strain, with some slight differences regarding compounds 3 and 5 . This confirms the need to include in the antifungal screening not only standard strains with a stable, defined phenotype and genotype, but also clinical isolates that are representative of pathogens circulating in the population [24]. Moreover, all the selected compounds showed antifungal activity against $C$. lusitaniae, even if to a different extent, and a good effect was observed for 3, 4, 7, and 28. On the contrary, compounds 1, 4, 14, and 28 proved to inhibit $C$. utilis growth, with $\mathbf{1 4}$ and $\mathbf{2 8}$ being the most potent, while only 3 and $\mathbf{2 8}$ affected $C$. parapsilosis growth. Among the tested clinical strains, C. krusei, C. glabrata, and C. tropicalis exhibited the most resistant phenotypes, only being susceptible to chalcone 28 . This is a promising result as the two latter non-Candida species account for the majority of all the infections not caused by $C$. albicans and their increasing resistance to the azole drug class is of great concern. In addition, chalcone $\mathbf{2 8}$ exhibited a similar inhibitory activity compared to FLC for C. krusei and against some clinical isolates IC $_{50}$ values were around $25 \mu \mathrm{M}$. These values perfectly comply with the criteria suggested by Cos et al. [24] defining the anti-infective potential of a small molecule.

Table 3. Antifungal effect determined for compounds 1, 3-5, 7, 14, 28 and for the control FLC against various Candida spp. The activities are expressed as $\mathrm{IC}_{50}$ values ${ }^{\mathrm{a}, \mathrm{b}}[\mu \mathrm{M}$ (above) and in $\mu \mathrm{g} / \mathrm{mL}$ (below)].

\begin{tabular}{|c|c|c|c|c|c|c|c|}
\hline Compound & C. albicans & C. parapsilosis & C. lusitaniae & C. tropicalis & C. krusei & C. glabrata & C. utilis \\
\hline \multirow{2}{*}{1} & $\begin{array}{c}62.9 \\
{[45.9-79.8]}\end{array}$ & 200 & 100 & 200 & 200 & 200 & $\begin{array}{c}84.5 \\
{[77.5-92.2]}\end{array}$ \\
\hline & $\begin{array}{c}16.3 \\
{[11.9-20.6]}\end{array}$ & 51.7 & 25.9 & 51.7 & 51.7 & 51.7 & $\begin{array}{c}21.9 \\
{[20.0-23.9]} \\
\end{array}$ \\
\hline \multirow{2}{*}{3} & 100 & $\begin{array}{c}41.5 \\
{[27.2-63.1]}\end{array}$ & $\begin{array}{c}38.5 \\
{[29.7-50.0]}\end{array}$ & $>200$ & $>200$ & $>200$ & 100 \\
\hline & 27.7 & $\begin{array}{c}11.5 \\
{[7.5-17.5]}\end{array}$ & $\begin{array}{c}10.7 \\
{[8.2-13.8]}\end{array}$ & $>55.3$ & $>55.3$ & $>55.3$ & 27.7 \\
\hline \multirow{2}{*}{4} & $\begin{array}{c}69.6 \\
{[51.7-93.7]}\end{array}$ & $>200$ & $\begin{array}{c}34.6 \\
{[21.5-55.8]}\end{array}$ & 200 & 200 & 200 & $\begin{array}{c}96.7 \\
{[90.8-102.9]}\end{array}$ \\
\hline & $\begin{array}{c}19.3 \\
{[14.3-25.9]}\end{array}$ & $>55.3$ & $\begin{array}{c}9.6 \\
{[5.9-15.4]}\end{array}$ & 55.3 & 55.3 & 55.3 & $\begin{array}{c}26.8 \\
{[25.1-28.5]}\end{array}$ \\
\hline \multirow{2}{*}{5} & 100 & 200 & $\begin{array}{c}47.9 \\
{[37.2-61.9]}\end{array}$ & $>200$ & $>200$ & $>200$ & 100 \\
\hline & 29.5 & 58.9 & $\begin{array}{c}14.1 \\
{[11.0-18.2]}\end{array}$ & $>58.9$ & $>58.9$ & $>58.9$ & 29.5 \\
\hline \multirow{2}{*}{7} & $\begin{array}{c}32.1 \\
{[26.4-39.0]}\end{array}$ & 100 & $\begin{array}{c}31.7 \\
{[26.3-38.1]}\end{array}$ & $>200$ & 100 & 100 & 100 \\
\hline & $\begin{array}{c}8.4 \\
{[6.9-10.1]}\end{array}$ & 26.0 & $\begin{array}{c}8.2 \\
{[6.8-9.9]}\end{array}$ & $>52.0$ & 26.0 & 26.0 & 26.0 \\
\hline \multirow{2}{*}{14} & $\begin{array}{c}31.4 \\
{[25.5-40.2]}\end{array}$ & 100 & $\begin{array}{c}48.8 \\
{[28.3-66.4]}\end{array}$ & 200 & 200 & 200 & $\begin{array}{c}33.7 \\
{[27.8-40.8]}\end{array}$ \\
\hline & $\begin{array}{c}10.6 \\
{[21.1-19.9]}\end{array}$ & 33.7 & $\begin{array}{c}14.8 \\
{[9.6-22.4]}\end{array}$ & 67.5 & 67.5 & 67.5 & $\begin{array}{c}11.4 \\
{[9.4-13.8]}\end{array}$ \\
\hline \multirow{2}{*}{28} & $\begin{array}{c}48.1 \\
{[41.2-56.0]}\end{array}$ & $\begin{array}{c}36.8 \\
{[30.2-44.8]}\end{array}$ & $\begin{array}{c}26.5 \\
{[19.9-35.2]}\end{array}$ & $\begin{array}{c}26.6 \\
{[24.1-29.3]}\end{array}$ & $\begin{array}{c}63.5 \\
{[59.1-68.3]}\end{array}$ & $\begin{array}{c}37.1 \\
{[31.7-43.5]}\end{array}$ & $\begin{array}{c}29.6 \\
{[27.0-32.4]}\end{array}$ \\
\hline & $\begin{array}{c}23.9 \\
{[20.4-27.8]}\end{array}$ & $\begin{array}{c}18.3 \\
{[15.0-22.2]}\end{array}$ & $\begin{array}{c}13.1 \\
{[9.9-17.5]}\end{array}$ & $\begin{array}{c}13.2 \\
{[12.0-14.5]}\end{array}$ & $\begin{array}{c}31.5 \\
{[29.3-33.9]}\end{array}$ & $\begin{array}{c}18.4 \\
{[15.7-21.6]}\end{array}$ & $\begin{array}{c}14.7 \\
{[13.4-16.1]}\end{array}$ \\
\hline \multirow{2}{*}{ FLC } & $\begin{array}{c}0.42 \\
{[0.29-0.61]}\end{array}$ & $\begin{array}{c}0.037 \\
{[0.02-0.07]}\end{array}$ & $\begin{array}{c}0.05 \\
{[0.01-0.2]}\end{array}$ & 0.40 & $\begin{array}{c}64.6 \\
{[44.3-94.2]}\end{array}$ & $\begin{array}{c}14.4 \\
{[12.6-16.4]}\end{array}$ & $\begin{array}{c}1.56 \\
{[0.96-2.53]}\end{array}$ \\
\hline & $\begin{array}{c}0.13 \\
{[0.09-0.19]}\end{array}$ & $\begin{array}{c}0.01 \\
{[0.01-0.02]}\end{array}$ & $\begin{array}{c}0.015 \\
{[0.003-0.06]}\end{array}$ & $(0.31-0.52)$ & $\begin{array}{c}19.8 \\
{[13.6-28.9]}\end{array}$ & $\begin{array}{c}4.4 \\
{[3.9-5.0]}\end{array}$ & $\begin{array}{c}0.5 \\
{[0.3-0.8]}\end{array}$ \\
\hline
\end{tabular}

${ }^{\mathrm{a}} \mathrm{IC}_{50}$ value is defined as the concentration giving rise to an inhibition of growth of $50 \%$ compared to the drug-free control. ${ }^{b}$ Data are reported as mean values and $95 \%$ confidence interval. 
The potency of chalcone 28 is also demonstrated by the distinctive sigmoidal form of the dose-response curves (Figure 2 and Table S1). Curves reached 100\% of response, indicating its efficacy to completely inhibit yeast growth, and the steep slopes suggested its high effectiveness against the tested strains, as small increases in the doses corresponded to great responses. Just as exceptions, the efficacy of chalcone $\mathbf{2 8}$ was slightly lower towards C. parapsilosis and C. lusitaniae compared to the other clinical isolates, and a shallower curve with a lower slope factor was generated.
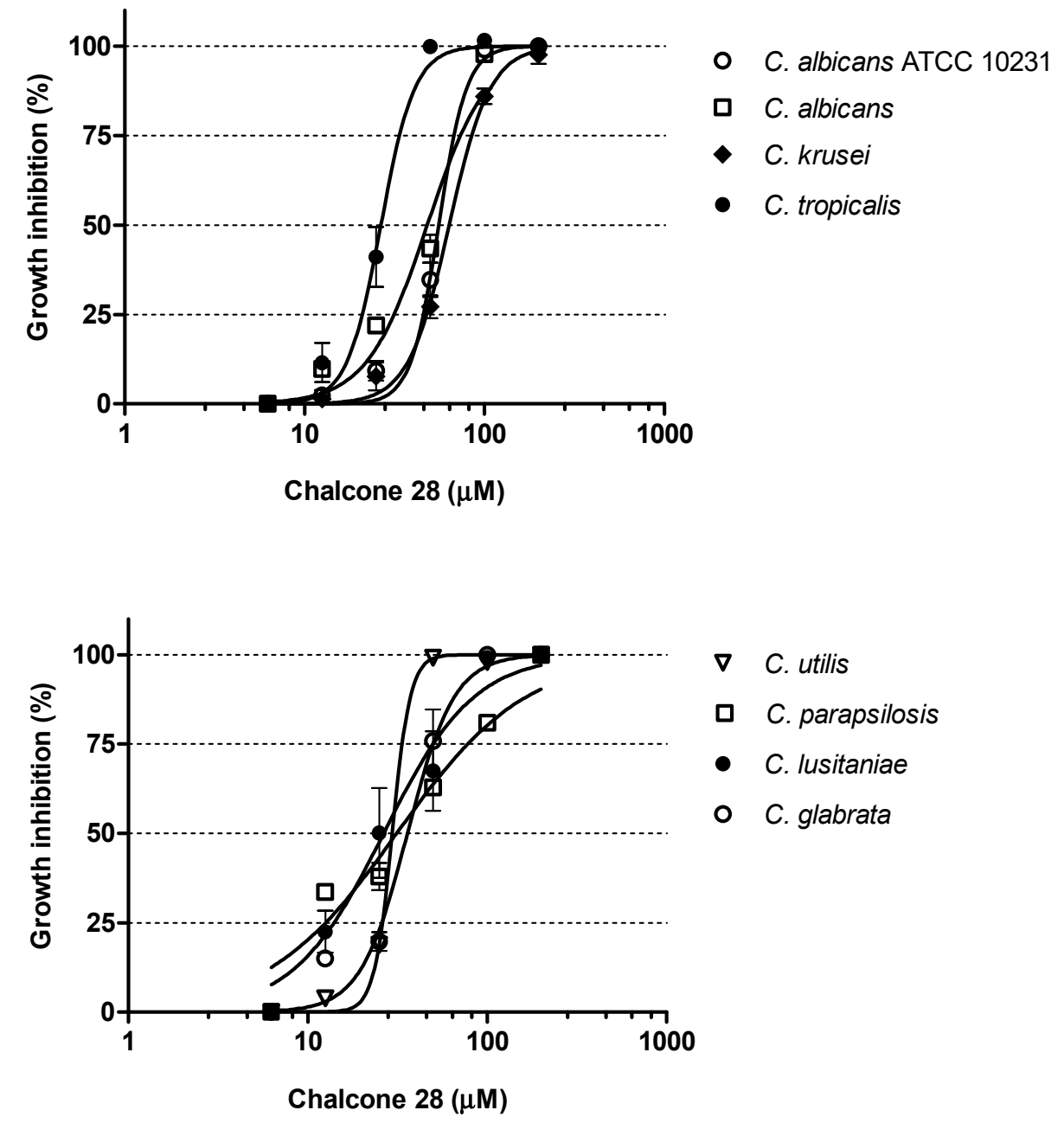

Figure 2. Dose-response curves of chalcone 28 obtained with C. albicans ATCC 10231 and all Candida spp. clinical isolates.

Concerning the activity of the seven selected analogues against the other clinically relevant yeasts, they exhibited an overall strong inhibitory effect on C. neoformans and R. mucilaginosa compared to FLC (Table 4). Chalcones 5, 7, and 28 displayed potent two-digit micromolar $\mathrm{IC}_{50}$ values on the C. neoformans isolate, indicating a potentially relevant clinical impact; indeed, infections by this opportunistic pathogen give rise to most cases of AIDS-related meningitis worldwide, and there has been an increase in the percentage of Cryptococcus isolates found to have some degree of FLC resistance. Chalcone 28 exhibited against this pathogen the same potency and efficacy observed for the other tested Candida spp. isolates (Figure S1 and Table S2). 
Table 4. Antifungal effect determined for compounds 1, 3-5, 7, 14, 28 and for the control FLC against various non-Candida yeast strains. The activities are expressed as $\mathrm{IC}_{50}$ values ${ }^{\mathrm{a}, \mathrm{b}}[\mu \mathrm{M}(\mathrm{above})$ and in $\mu \mathrm{g} / \mathrm{mL}$ (below)].

\begin{tabular}{|c|c|c|c|}
\hline Compound & C. neoformans & S. clavata & R. mucilaginosa \\
\hline \multirow{2}{*}{1} & 26.4 [22.6-30.9] & 200 & 83.7 [70.1-100.0] \\
\hline & $6.8[5.8-8.0]$ & 51.7 & 21.7 [18.1-25.9] \\
\hline \multirow{2}{*}{3} & $35.2[31.7-39.0]$ & 37.2 [30.9-44.9] & $>200$ \\
\hline & 9.7 [8.8-10.8] & $10.3[8.5-12.4]$ & 55.3 \\
\hline \multirow{2}{*}{4} & $27.1[22.5-32.7]$ & 200 & 81.8 [75.1-89.0] \\
\hline & $7.5[6.2-9.0]$ & 55.3 & $22.6[20.8-24.6]$ \\
\hline \multirow{2}{*}{5} & 18.0 [15.9-40.5] & 100 & 76.9 [63.5-93.1] \\
\hline & 5.3 [4.7-11.9] & 29.5 & $22.7[18.7-27.4]$ \\
\hline \multirow{2}{*}{7} & 15.6 [14.0-16.9] & 37.0 [26.9-50.9] & 80.0 [71.5-89.5] \\
\hline & $4.1[3.6-4.4]$ & $9.6[7.0-13.2]$ & 20.8 [18.6-23.3] \\
\hline \multirow{2}{*}{14} & $28.4[22.6-35.6]$ & 100 & 100 \\
\hline & $9.6[7.6-12.0]$ & 33.7 & 33.7 \\
\hline \multirow{2}{*}{28} & 17.7 [15.6-20.0] & $27.9[22.2-35.0]$ & $48.5[42.1-50.9]$ \\
\hline & 8.8 [7.7-9.9] & 13.8 [11.0-17.4] & 21.4 [20.9-25.2] \\
\hline \multirow{2}{*}{ FLC } & 255.9 [93.68-699] & $0.04[0.01-0.08]$ & 1605 [549-4694] \\
\hline & $78.4[28.7-214.1]$ & $0.012[0.003-0.025]$ & 491 [168-1437] \\
\hline
\end{tabular}

a,b $\mathrm{IC}_{50}$ value is defined as the concentration giving rise to an inhibition of growth of $50 \%$ compared to the drug-free control. Data are reported as mean values and $95 \%$ confident interval.

\subsubsection{Inhibition of Yeast-to-Hyphae Morphological Transition}

The ability of the seven chalcones to weaken microbial virulence was further investigated in C. albicans ATCC 10231. A key virulence factor expressed by C. albicans that significantly contributes to its pathogenicity is the transition of yeast cells to filamentous cells. The formation of germ tube and mycelium is an essential process for host tissue invasion, damage to mucosal epithelia, escape from host immune cells, and blood dissemination. Additionally, the conversion of C. albicans from yeast to hyphae is related to the expression of specific adhesins that are involved in the formation of biofilms [4]. For this purpose, C. albicans was cultured for $2 \mathrm{~h}$ in an RPMI-1640 medium supplemented with serum at $10 \%$ and containing the chalcones $\mathbf{1}, \mathbf{3}-\mathbf{5}, \mathbf{7}, \mathbf{1 4}$, and 28 at $\mathrm{IC}_{50}$ values, and then evaluated for their effect on hyphae formation.

As presented in Figure 3, untreated cells exhibited a prevalence of branched filamentous cells, while cells treated with the compounds at $\mathrm{IC}_{50}$ values showed different morphological forms with blastospores, budding cells, and filamentous cells. The ranking of yeast-to-hyphae inhibition, as determined by the visual observation of cultures, was $\mathbf{1}<\mathbf{2 8}<\mathbf{1 4}<\mathbf{4}<\mathbf{5}<\mathbf{3}<7$. In particular, the C. albicans control strain treated with chalcone 7 mainly formed blastospores, some rare budding cells but no hyphae; thus, 7 interfered in vitro with the morphological plasticity of $C$. albicans, which is a crucial virulence determinant for epithelial and endothelial invasion and accession to the bloodstream. 

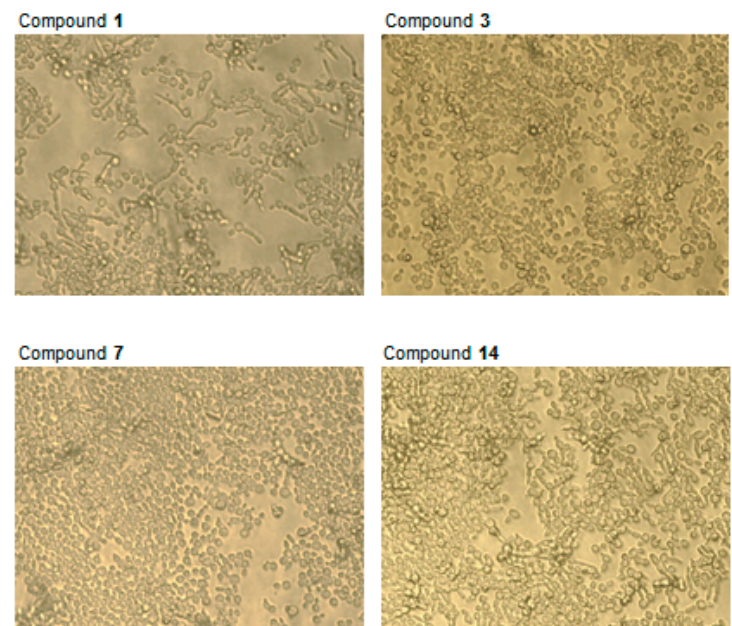
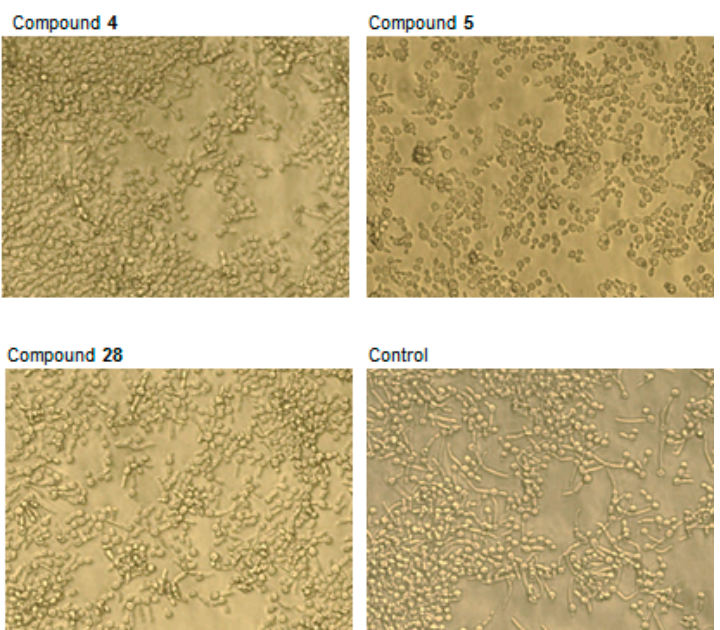

Figure 3. Structural framework of C. albicans ATCC 10231 grown for $2 \mathrm{~h}$ in RPMI1640-FCS culture medium containing chalcones at $\mathrm{IC}_{50}$ values. Visual differences in cell morphotypes can be observed among the positive untreated control and cells at the different experimental conditions. DMSO was used at $0.5 \%$ as the solvent control and it did not affect hyphal transition.

\subsubsection{Inhibition of C. albicans Filamentation in Hyphal-Inducing Media}

In order to further support the activity of some selected chalcones against virulence attributes of C. albicans ATCC 10231 the standard test simulating the filamentation into the tissue (i.e., "Spider" agar assay) was carried out and results are shown in Figure 4. Filaments (hyphae/pseudohyphae) seen under a light microscope at the edge of the colonies in the control medium and in the solvent control were large and formed a broad spider-branched zone around the mycelium. On the contrary, C. albicans spotted on the Spider medium containing chalcones 5 and $\mathbf{7}$ at $\mathrm{IC}_{50}$ values were unable to penetrate the medium and only blastospores were visualized in the dense mass of the colonies. These data suggested that these compounds inhibit not only the first stage of hyphal growth involving the production of germ tube and hyphae, but also the ability of $C$. albicans to invade a solid medium in the long term.
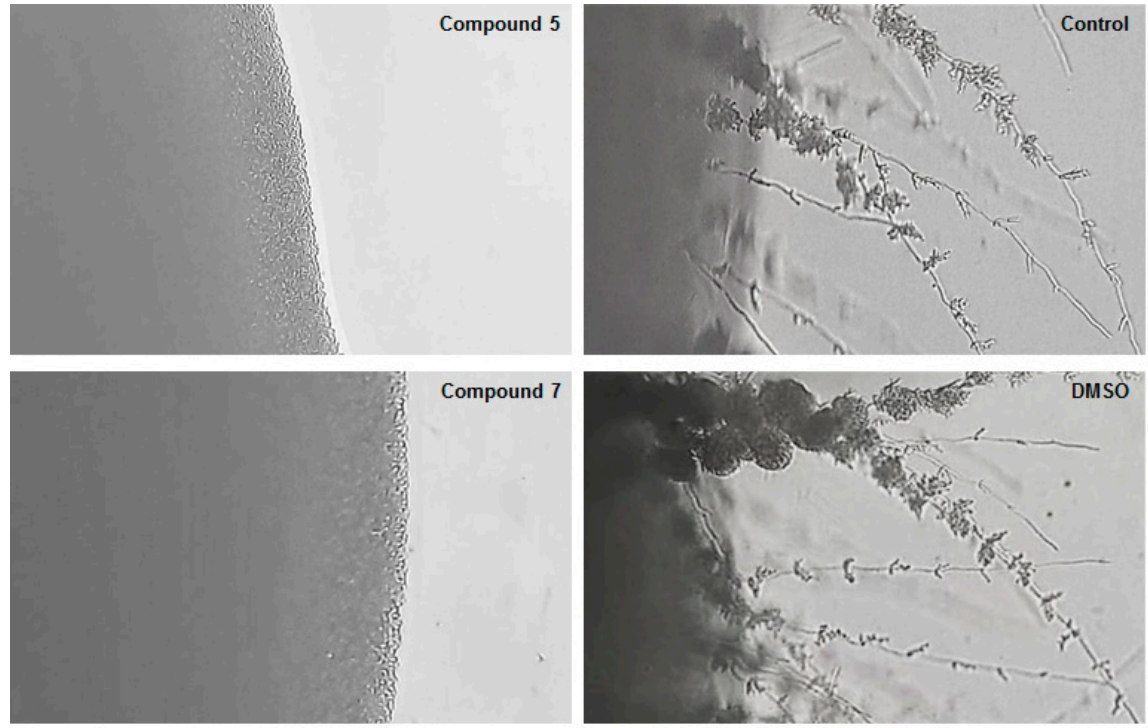

Figure 4. Impact of chalcones 5 and 7 at $\mathrm{IC}_{50}$ values on C. albicans ATCC 10231 invasion potential determined in the Spider agar assay. The colony edges were imaged using a light microscope at the different experimental conditions. DMSO, used as control, did not interfere with C. albicans filamentation. The presence of pseudohyphal growth area at the colony edges was determined using a light microscope. 


\subsubsection{Antibiofilm Activity}

Compelling evidences suggest biofilm formation is very often associated to C. albicans infections and is responsible for the therapeutic failure and/or resistance phenomena. Biofilms are complex functional communities of one or more species of microorganisms that are encapsulated in a matrix of extracellular polymeric substances. Their development is caused by the adhesion of the microorganisms community to a solid (inert or living) surface. Indeed, the formed biofilm being a complex matrix represents a serious virulence factor that is difficult to eradicate. This physical barrier hampers the antifungal agent from reaching the pathogens and exerting its activity. The antibiofilm effects of the most active compounds, also able to influence yeast morphogenesis $(\mathbf{1}, \mathbf{3 - 5}, \mathbf{7}, \mathbf{1 4}$, and 28), were investigated in vitro on C. albicans ATCC 10231, evaluating their ability to inhibit the biofilm formation process and/or disrupt a mature biofilm. In details, $C$. albicans cells were incubated in the presence of these compounds at $\mathrm{IC}_{50}$ values and, following a 24-h incubation, the biofilm mass was quantitatively evaluated by crystal violet staining and destaining solution that was measured spectrophotometrically. As reported in Figure 5, even if the solvent contributed to the inhibition, all tested compounds were able to effectively reduce the formation of the biofilm mass with the following order of potency: $3>4 \sim 7 \sim 5 \sim 14 \sim 28>1$. This effect could be ascribed to the change in cell wall components that is critical for $C$. albicans adhesion to surfaces; indeed, chalcones may act towards fungal cells by interfering with different biosynthesis, all contributing to disrupt the fungal cell wall [25].

In parallel, the selected compounds were added to a preformed mature biofilm of $C$. albicans and their effect was expressed as the reduction of the biofilm metabolic activity. The data shown in Figure 5 demonstrated that only two molecules ( 5 and 7 ) slightly diminished the metabolism of sessile cells, at a statistically significant level, even if to a minimal extent $(<25 \%)$. As currently available antifungals have marginal effect against biofilms [26], the activities of these chalcones are therefore of relevance, and new therapeutic agents targeting biofilms are desperately needed, mainly for the treatment of persistent device-associated infections. Interestingly, chalcone 7 displayed remarkable antifungal activity, specifically against $C$. albicans, affecting several virulence factors: yeast growth, germ tube formation, and biofilm production. In addition, among the seven active compounds, it exhibited the greatest inhibitory activity against the clinical isolate of $C$. albicans $\left(\mathrm{IC}_{50}=32.1 \mu \mathrm{M}\right)$.
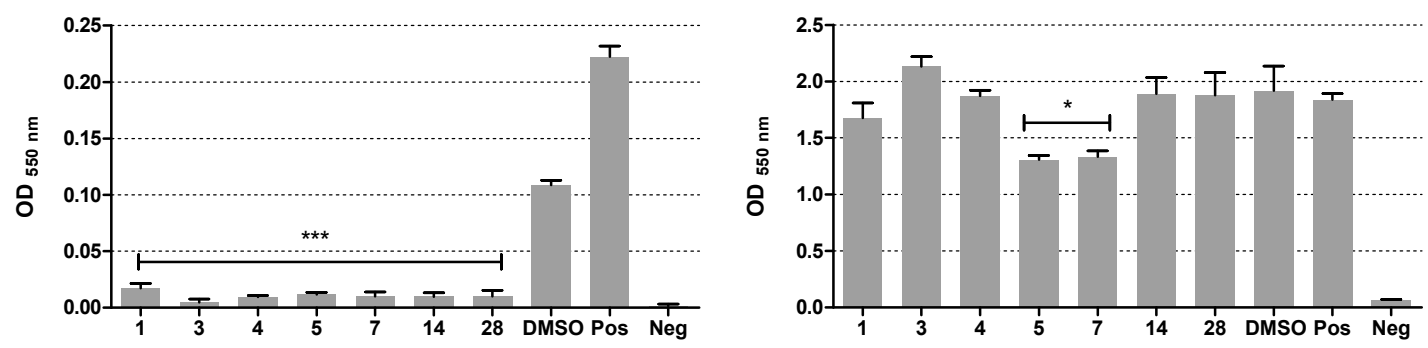

Figure 5. Antibiofilm activity of the selected chalcones on biofilm formation (left panel) and disruption (right panel). Values are reported as mean $\pm \mathrm{SD}$. Biofilm formation: ${ }^{* *} p<0.0005$ for chalcones 1, 3-5, 7, 14, and 28 vs. DMSO/positive control. Biofilm disruption: ${ }^{*} p<0.05$ for chalcones 5 and 7 vs. $\mathrm{DMSO} /$ positive control. The negative control consists of the medium only.

\section{Discussion}

A small library of 40 chalcone-based analogues was evaluated for their antifungal potential. The study delivered three lead molecules $(28,5$, and 7$)$ endowed with relevant antifungal features. Analogue 28 proved to be the most interesting since it exhibited a broad spectrum of activity, being able to effectively inhibit several Candida spp. such as C. albicans, C. parapsilosis, C. lusitaniae, C. krusei, C. tropicalis, C. glabrata, and C. utilis, and a broad array of clinically relevant yeasts, including C. neoformans, which is responsible of one of the most fatal meningoencephalitis in AIDS patients 
across the globe. The concomitant presence of the phenylpiperazine, protonable at physiological $\mathrm{pH}$, and the 4-F-phenyl moiety could be responsible for the good antifungal effect of this chalcone.

The antifungal effect of compounds $\mathbf{5}$ and $\mathbf{7}$ could mainly be ascribed to an antivirulence effect; as they weakened hyphae and biofilm production, factors strongly involved in C. albicans pathogenesis, this behavior perfectly meets the current paradigm of anti-infective therapeutics [27]. The presence of a halogen (chlorine or fluorine atom) in the 5-position of the chalcone A-ring seems to be a favorable substitution pattern.

Overall, the pyridine heterocycle as B-ring demonstrated to confer an impressive ability to inhibit C. albicans growth; unfortunately, this effect is likely due to the intrinsically toxic effects of the molecules. However, this last sub-set represents a promising starting point in optimization efforts. In fact, we anticipate that it will be possible to overcome the current drawbacks by proper functionalization of the heterocyclic nitrogen atom.

\section{Experimental Section}

\subsection{Chemistry}

Starting materials, unless otherwise specified, were used as high-grade commercial products. Solvents were of analytical grade. Reaction progress was followed by thin-layer chromatography (TLC) on precoated silica gel plates (Merck Silica Gel 60 F254, Darmstadt, Germany) and then visualized with a UV 254 lamplight. Chromatographic separations were performed on Merck silica gel columns by the flash method (Kieselgel 40, 0.040-0.063 mm, Merck, Darmstadt, Germany). Melting points were determined in open glass capillaries, using a Büchi SMP-20 apparatus (Büchi Italia s.r.l., Cornaredo, $\mathrm{Mi}$, Italy) and are uncorrected. ${ }^{1} \mathrm{H}-\mathrm{NMR}$ and ${ }^{13} \mathrm{C}-\mathrm{NMR}$ spectra were recorded on a Varian Gemini spectrometer (Scientific instruments, Palo Alto, CA, USA) $400 \mathrm{MHz}$ and $101 \mathrm{MHz}$, respectively, and chemical shifts $(\delta)$ are reported as parts per million $(\mathrm{ppm})$ values relative to tetramethylsilane (TMS) as internal standard; unless otherwise indicated, $\mathrm{CDCl}_{3}$ was used as the solvent. Standard abbreviations indicating spin multiplicities are given as follows: $s$ (singlet), $d$ (doublet), $t$ (triplet), br (broad), q (quartet), or $\mathrm{m}$ (multiplet); coupling constants $(J)$ are reported in Hertz (Hz). Mass spectra were recorded on a Waters ZQ 4000 apparatus Waters Alliance, San Diego, CA, USA) operating in electrospray mode (ES). Analyses indicated by the symbols of the elements were within $\pm 0.4 \%$ of the theoretical values. Compounds were named relying on the naming algorithm developed by CambridgeSoft Corporation and used in Chem-BioDraw Ultra 14.0 (PerkinElmer Inc., Waltham, MA, USA).

\subsubsection{Williamson Reaction: General Procedure}

A mixture of the selected acetophenone (1.0 eq), alkyl halide (1.0 or 1.1 eq), $\mathrm{K}_{2} \mathrm{CO}_{3}$ (1.0 eq) in acetone was heated under reflux for $6-10 \mathrm{~h}$; reaction progress was monitored by TLC. Upon reaction completion, the mixture was hot filtered and the solvent was evaporated under reduced pressure. The resulting crude product was purified by column chromatography using a mixture of petroleum ether $(\mathrm{PE})$ / ethyl acetate $(\mathrm{EtOAc})$ as eluent to give the desired pure product.

1-(4-(2-chloroethoxy)-2-hydroxyphenyl)ethan-1-one (46). Reaction of 2,4-dihydroxyacetophenone (0.76 g, $5.0 \mathrm{mmol})$ and 1-bromo-2-chloroethane $(0.94 \mathrm{~g}, 0.45 \mathrm{~mL}, 5.0 \mathrm{mmol})$ gave a crude product that was purified by column chromatography (PE/EtOAc 4:1) producing 46 as a solid $(0.55 \mathrm{~g}), 85 \%$ yield. ${ }^{1} \mathrm{H}-\mathrm{NMR} \delta 2.60\left(\mathrm{~s}, 3 \mathrm{H}, \mathrm{COCH}_{3}\right), 3.83\left(\mathrm{t}, 2 \mathrm{H}, J=6.0 \mathrm{~Hz}, \mathrm{CH}_{2} \mathrm{Cl}\right), 4.26\left(\mathrm{t}, 2 \mathrm{H}, J=6.0 \mathrm{~Hz}, \mathrm{OCH}_{2}\right), 6.40(\mathrm{~d}$, $J=2.2 \mathrm{~Hz}, 1 \mathrm{H}, \mathrm{H}-3) 6.48(\mathrm{dd}, J=8.0$ and $2.2 \mathrm{~Hz}, 1 \mathrm{H}, \mathrm{rH}-5), 7.65(\mathrm{~d}, 1 \mathrm{H}, J=9.2 \mathrm{~Hz}, \mathrm{H}-6) .{ }^{13} \mathrm{C}-\mathrm{NMR} \delta$ $26.3,60.55,69.21,103.25,106.74,131.00,165.47,165.87,201.88$.

1-(4-(2-chloroethoxy)-2-methoxyphenyl)ethan-1-one (47). Reaction of 43 (0.18 g, $0.87 \mathrm{mmol})$ and methyl iodide $(0.14 \mathrm{~g}, 0.06 \mathrm{~mL}, 0.96 \mathrm{mmol})$ gave a crude product that was purified by column chromatography (PE/AcOEt 9:1) producing 47 as a transparent oil $(0.13 \mathrm{~g}), 78 \%$ yield. ${ }^{1} \mathrm{H}-\mathrm{NMR} \delta 2.65\left(\mathrm{~s}, 3 \mathrm{H}, \mathrm{COCH}_{3}\right)$, 
$3.85\left(\mathrm{t}, 2 \mathrm{H}, J=6.0 \mathrm{~Hz}, \mathrm{CH}_{2} \mathrm{Cl}\right), 3.96\left(\mathrm{~s}, 3 \mathrm{H}, \mathrm{OCH}_{3}\right), 4.30\left(\mathrm{t}, 2 \mathrm{H}, J=6.0 \mathrm{~Hz}, \mathrm{OCH}_{2}\right), 6.50(\mathrm{~d}, J=2.2 \mathrm{~Hz}, 1 \mathrm{H}$, H-3) $6.58(\mathrm{dd}, J=8.0$ and $2.2 \mathrm{~Hz}, 1 \mathrm{H}, \mathrm{H}-5), 7.67(\mathrm{~d}, 1 \mathrm{H}, J=9.2 \mathrm{~Hz}, \mathrm{H}-6) .{ }^{13} \mathrm{C}-\mathrm{NMR} \delta 26.10,42.54,45.97$, $75.44,101.23,106.78,119.84,130.67,161.74,164.74,199.55$.

1-(4-(2-hydroxyethoxy)phenyl)ethan-1-one (50). Reaction of 4-hydroxyacetophenone (5.0 mmol, $0.90 \mathrm{~g}$ ) and 2-bromoethanol ( $5.5 \mathrm{mmol}, 0.68 \mathrm{~g}$ ) gave the crude final product that was purified by column chromatography (PE/EtOAc 4:1) to produce 50 as a white solid (0.63 g), 75\% yield. ${ }^{1} \mathrm{H}-\mathrm{NMR}$ (acetone $\left.\mathrm{d}_{6}\right) \delta 2.58\left(\mathrm{~s}, 3 \mathrm{H}, \mathrm{CH}_{3}\right), 3.92-3.98\left(\mathrm{~m}, 2 \mathrm{H}, \mathrm{CH}_{2} \mathrm{OH}\right), 4.07(\mathrm{t}, J=4.4 \mathrm{~Hz}, 1 \mathrm{H}, \mathrm{OH}), 4.15(\mathrm{t}, J=6.4 \mathrm{~Hz}, 2 \mathrm{H}$, $\left.\mathrm{OCH}_{2}\right), 6.96\left(\mathrm{~d}, J=8.6 \mathrm{~Hz}, 2 \mathrm{H}, \mathrm{H}-3\right.$ and H-5), $7.96\left(\mathrm{~d}, J=8.8 \mathrm{~Hz}, 2 \mathrm{H}, \mathrm{H}-2\right.$ and H-6). ${ }^{13} \mathrm{H}-\mathrm{NMR} \delta 26.88$, $64.22,69.15,127.42,128.75,129.12,129.66,166.84,198.05$.

1-(4-((3-methylbut-2-en-1-yl)oxy)phenyl)ethan-1-one (51). Reaction of 4-hydroxyacetophenone (0.76 g, $5.0 \mathrm{mmol})$ and 3,3-dimethylallylbromide $(0.82 \mathrm{~g}, 5.5 \mathrm{mmol})$ gave a crude final product that was purified by column chromatography (PE/EtOAc 9:1) to produce 51 as a transparent oil (0.97 g), 95\% yield. ${ }^{1} \mathrm{H}-\mathrm{NMR} \delta 1.78\left(\mathrm{~s}, 3 \mathrm{H}, \mathrm{CH}_{3}\right), 1.79\left(\mathrm{~s}, 3 \mathrm{H}, \mathrm{CH}_{3}\right), 2.54\left(\mathrm{~s}, 3 \mathrm{H}, \mathrm{COCH}_{3}\right), 4.57\left(\mathrm{~d}, J=6.8 \mathrm{~Hz}, 2 \mathrm{H}, \mathrm{OCH}_{2}\right), 5.47$ $(\mathrm{t}, J=6.8 \mathrm{~Hz}, 1 \mathrm{H},=\mathrm{CH}), 6.92\left(\mathrm{~d}, J=8.8 \mathrm{~Hz}, 2 \mathrm{H}, \mathrm{H}-3\right.$ and H-5), $7.92\left(\mathrm{~d}, J=7.2 \mathrm{H}-2\right.$ and H-6). ${ }^{13} \mathrm{C}-\mathrm{NMR} \delta$ 18.1, 25.7, 26.1, 64.9, 114.2, 118.9, 130.1, 130.4, 138.7, 162.7, 196.6. ${ }^{13}$ C-NMR $\delta 18.88,26.55,64.58,114.47$, $114.97,12.032,129.16,129.74,130.54,138.17,162.28,198.27$.

1-(4-(prop-2-yn-1-yloxy)phenyl)ethan-1-one (52). Reaction of 4-hydroxyacetophenone (0.76 g, $5.0 \mathrm{mmol})$ and propargyl bromide solution $80 \mathrm{wt} \%$ in toluene $(0.80 \mathrm{~g}, 5.5 \mathrm{mmol})$ gave the crude final product that was purified by column chromatography (PE/EtOAc 9:1) to produce 52 as a solid $(0.90 \mathrm{~g}), 93 \%$ yield, mp: 73-74 ${ }^{\circ} \mathrm{C} .{ }^{1} \mathrm{H}-\mathrm{NMR} \delta 2.54-2.56\left(\mathrm{~m}, 4 \mathrm{H}, \mathrm{CH}\right.$ and $\left.\mathrm{COCH}_{3}\right), 4.76\left(\mathrm{~d}, J=4.2 \mathrm{~Hz}, 2 \mathrm{H}, \mathrm{OCH}_{2}\right), 7.01(\mathrm{dd}$, $J=2.0$ and $8.0 \mathrm{~Hz}, 2 \mathrm{H}, \mathrm{H}-3$ and H-5), 6.95 (dd, $J=2.0$ and $8.0 \mathrm{~Hz}, 2 \mathrm{H}, \mathrm{H}-2$ and H-6). ${ }^{13} \mathrm{C}-\mathrm{NMR} \delta 26.33$, 56.47. 78.91, 79.32, 114.21, 114.51, 129.06, 129.48, 162.47, 198.41.

1-(2-Methoxy-4-(2-(4-phenylpiperazin-1-yl)ethoxy)phenyl)ethan-1-one (48). A mixture of 47 (0.26 g, $1.0 \mathrm{mmol})$, phenylpiperazine $(0.24 \mathrm{~g}, 1.5 \mathrm{mmol})$ and TEA $(0.21 \mathrm{~mL}, 1.5 \mathrm{mmol})$ in THF was stirred at $\mathrm{rt}$ for $18 \mathrm{~h}$. The solvent was removed by evaporation under reduced pressure and the crude was purified by column chromatography (DCM/MeOH/ $\mathrm{NH}_{4} \mathrm{OH}$ 9.5:0.45:0.05) to give 48 as a dense oil $(0.30 \mathrm{~g}), 87 \%$ yield; hydrochloride salt mp 131-132 ${ }^{\circ} \mathrm{C} .{ }^{1} \mathrm{H}-\mathrm{NMR} \delta 2.50\left(\mathrm{~s}, 3 \mathrm{H}, \mathrm{COCH}_{3}\right), 2.72-2.76(\mathrm{~m}, 4 \mathrm{H}$, piperazine), $2.90\left(\mathrm{t}, J=5.6 \mathrm{~Hz}, 2 \mathrm{H}, \mathrm{NCH}_{2}\right), 3.22-3.25(\mathrm{~m}, 4 \mathrm{H}$, piperazine $), 4.19\left(\mathrm{t}, J=5.6 \mathrm{~Hz}, 2 \mathrm{H}, \mathrm{OCH}_{2}\right), 6.45(\mathrm{~d}$, $J=1.2 \mathrm{~Hz}, 1 \mathrm{H}, \mathrm{H}-3), 6.48(\mathrm{dd}, J=8.4$ and $1.2 \mathrm{~Hz}, 1 \mathrm{H}, \mathrm{H}-5), 6.89\left(\mathrm{t}, J=8.4 \mathrm{~Hz}, 1 \mathrm{H}, \mathrm{H}-4^{\prime}\right), 6.94(\mathrm{~d}$, $J=8.4 \mathrm{~Hz}, 2 \mathrm{H}, \mathrm{H}-2^{\prime}$ and $\left.\mathrm{H}-6^{\prime}\right), 7.24-7.26\left(\mathrm{~m}, 2 \mathrm{H}, \mathrm{H}-3^{\prime}\right.$ and $\left.\mathrm{H}-5^{\prime}\right), 7.64(\mathrm{~d}, J=8.4 \mathrm{~Hz}, 1 \mathrm{H}, \mathrm{H}-6), 12.7(\mathrm{~s}, 1 \mathrm{H}$, OH). ${ }^{13}$ C-NMR $\delta 26.53,49.27,53.81,57.03,56.11,66.48,101.67,108.21,114.19,116.25,119.95,129.27$, $132.45,151.40,195.36$.

1-(4-((1-(2-hydroxyethyl)-1H-1,2,3-triazol-4-yl)methoxy)-2-methoxyphenyl)ethan-1-one (49). A mixture of 45 (0.15 g, $0.73 \mathrm{mmol}), 2$-azidoethan-1-ol (0.08 g, $0.95 \mathrm{mmol}), \mathrm{CuSO}_{4}(0.02 \mathrm{~g})$, Na-ascorbate $(0.07 \mathrm{~g}$, $0.37 \mathrm{mmol})$ in DMSO $(6.0 \mathrm{~mL})$ was stirred at room temperature for $8 \mathrm{~h}$. Then the mixture was poured in $\mathrm{H}_{2} \mathrm{O}$ and extracted with EtOAc $(12 \mathrm{~mL} \times 3)$. The combined organic layers were dried over $\mathrm{Na}_{2} \mathrm{SO}_{4}$, filtered and the solvent was removed under reduced pressure. The crude was purified by column chromatography (PE/AcOEt 7:3) producing 49 as an oily product $(0.19 \mathrm{~g}), 98 \%$ yield. ${ }^{1} \mathrm{H}-\mathrm{NMR} \delta 2.61$ $\left(\mathrm{s}, 3 \mathrm{H}, \mathrm{COCH}_{3}\right), 2.95(\mathrm{br}, 1 \mathrm{H}, \mathrm{OH}), 3.87\left(\mathrm{~s}, 3 \mathrm{H}, \mathrm{OCH}_{3}\right), 4.07\left(\mathrm{t}, J=5.2 \mathrm{~Hz}, 2 \mathrm{H}, \mathrm{NCH}_{2}\right), 4.51(\mathrm{t}, J=5.2 \mathrm{~Hz}$, $\left.2 \mathrm{H}, \mathrm{OCH}_{2}\right), 5.23\left(\mathrm{~s}, 2 \mathrm{H}, \mathrm{OCH}_{2}\right), 6.56(\mathrm{~d}, J=2.4 \mathrm{~Hz}, 1 \mathrm{H}, \mathrm{H}-3), 6.60(\mathrm{dd}, J=2.4$ and $7.6 \mathrm{~Hz}, 1 \mathrm{H}, \mathrm{H}-5), 7.78$ (s, 1H, triazole CH), $7.79(\mathrm{~d}, J=8.0 \mathrm{~Hz}, 1 \mathrm{H}, \mathrm{H}-6) .{ }^{13} \mathrm{C}-\mathrm{NMR} \delta 26.21,54.57,55.08,60.01,72.94,101.24$, $106.74,119.84,128.45,131.19,162.32,166.82$. 194.21.

\subsubsection{Claisen-Schmidt Reaction: General Procedure}

Route A. To a solution of the selected acetophenone (1.0 eq) and aldehyde (1.1 eq) in EtOH (10 mL) a $\mathrm{KOH}$ aqueous solution $(50 \% \mathrm{p} / \mathrm{v}, 1 \mathrm{~mL})$ was added dropwise and reaction mixture was stirred overnight at rt, diluted with $\mathrm{H}_{2} \mathrm{O}$, and neutralized with aqueous $6 \mathrm{~N} \mathrm{HCl}$. The formed solid/semisolid 
product was collected by vacuum filtration or extracted with a suitable solvent. The crude of reaction was then purified by column chromatography or by crystallization.

Route B. To a solution the selected acetophenone (1.0 eq) and aldehyde (1.1 eq) in $\mathrm{EtOH}(10 \mathrm{~mL})$, a solution of piperidine $(0.5 \mathrm{~mL})$ and acetic acid $(0.3 \mathrm{~mL})$ in EtOH $(1 \mathrm{~mL})$ was added. The reaction mixture was heated under reflux for $12-18 \mathrm{~h}$ and the reaction progress was monitored by TLC. The solvent was removed under reduced pressure and the crude of reaction was purified by column chromatography or crystallization.

Route C. A mixture the selected acetophenone (1.0 eq) and aldehyde (1.1 eq) in EtOH (10 mL), $\mathrm{Ba}(\mathrm{OH})_{2}$ (3.3 eq) was added. The reaction mixture was stirred at rt overnight; then diluted with $\mathrm{H}_{2} \mathrm{O}$ and neutralized with aqueous $6 \mathrm{~N} \mathrm{HCl}$. The formed solid/semisolid product was collected by vacuum filtration or extracted with a suitable solvent. The crude of reaction was then purified by column chromatography or by crystallization.

(E)-1-(5-Chloro-2-hydroxyphenyl)-3-phenylprop-2-en-1-one (1). Following route A, and starting from $5^{\prime}$-chloro-2'-hydroxyacetophenone $(0.17 \mathrm{~g}, 1.0 \mathrm{mmol})$ and benzaldehyde $(0.12 \mathrm{~g}, 1.1 \mathrm{mmol})$ a solid product was obtained that was collected by vacuum filtration. The crude of reaction was purified by crystallization from EtOH producing 1 as a yellowish solid $(0.22 \mathrm{~g}), 85 \%$ yield, mp $97-98^{\circ} \mathrm{C}$. ${ }^{1} \mathrm{H}-\mathrm{NMR} \delta$ $6.98(\mathrm{~d}, J=8.4 \mathrm{~Hz}, 1 \mathrm{H}, \mathrm{H}-3), 7.43(\mathrm{dd}, J=1.2$ and $8.4 \mathrm{~Hz}, 2 \mathrm{H}), 7.33-7.38\left(\mathrm{~m}, 2 \mathrm{H}, \mathrm{H}-3^{\prime}-\mathrm{H}^{\prime}\right), 7-50-7.54(\mathrm{~m}$, $2 \mathrm{H}, \mathrm{H}-2^{\prime}$ and $\left.\mathrm{H}-6^{\prime}\right), 7.60(\mathrm{~d}, J=16.0 \mathrm{~Hz}, 1 \mathrm{H}, \beta-\mathrm{CH}=), 7.86(1 \mathrm{H}, \mathrm{d}, J=1.2 \mathrm{~Hz}, \mathrm{H}-6), 8.04(\mathrm{~d}, J=15.6 \mathrm{~Hz}$, $1 \mathrm{H}, \alpha-\mathrm{CH}=), 12.55$ (br, $1 \mathrm{H}, \mathrm{OH}) .{ }^{13} \mathrm{C}-\mathrm{NMR} \delta 119.21,124.45,127.21,128.75,128.77,130.76,131.32,137.14$, 145.16, 161.08, 192.11. ESI-MS (m/z) $259(\mathrm{M}+1)$. HRMS ESI + [M + 1]: calcd for $\mathrm{C}_{15} \mathrm{H}_{11} \mathrm{ClO}_{2}, 259.0526$. Found: 259.0528 .

(E)-1-(5-Chloro-2-hydroxyphenyl)-3-(2-fluorophenyl)prop-2-en-1-one (2). Following route A, and starting from $5^{\prime}$-chloro-2'-hydroxyacetophenone $(0.17 \mathrm{~g}, 1.0 \mathrm{mmol})$ and 2-fluorobenzaldehyde $(0.14 \mathrm{~g}, 1.1 \mathrm{mmol})$, a solid product was obtained that was collected by vacuum filtration and crystallized from EtOH, producing 2 as a white solid $(0.13 \mathrm{~g}), 47 \%$ yield, $\mathrm{mp} 86-87^{\circ} \mathrm{C} .{ }^{1} \mathrm{H}-\mathrm{NMR} \delta 7.00(\mathrm{~d}, J=8.8 \mathrm{~Hz}, 1 \mathrm{H}, \mathrm{H}-3)$, 7.15-7.20 (m, 1H, Ar), 7.46-7.48 (m, 2H, Ar), 7.67-7.72 (m, 2H, Ar), $7.70(\mathrm{~d}, J=16.0 \mathrm{~Hz}, 1 \mathrm{H}, \beta-\mathrm{CH}=)$, 7.76-7.86 (m, 1H, Ar), $8.04(\mathrm{~d}, J=15.6 \mathrm{~Hz}, 1 \mathrm{H}, \alpha-\mathrm{CH}=), 12.67(\mathrm{br}, 1 \mathrm{H}, \mathrm{OH}) .{ }^{13} \mathrm{C}-\mathrm{NMR} \delta$ 115.16, 119.45, $121.21,123.11,124.25,128.27,128.75,131.86,137.32,145.16,161.58,192.31$. ESI-MS (m/z): 399 (M+23). HRMS ESI + [M + 1]: calcd for $\mathrm{C}_{15} \mathrm{H}_{10} \mathrm{ClFO}_{2}$, 277.0431. Found: 277.04533 .

(E)-1-(5-Chloro-2-hydroxyphenyl)-3-(3-fluorophenyl)prop-2-en-1-one (3). Following route A, and starting from $5^{\prime}$-chloro-2'-hydroxyacetophenone $(0.17 \mathrm{~g}, 1.0 \mathrm{mmol})$ and 3-fluorobenzaldehyde $(0.14 \mathrm{~g}$, $1.1 \mathrm{mmol}$ ), a solid product was obtained that was collected by vacuum filtration, purified by column chromatography (PE/EtOAc 9.5:0.5), and crystallized from EtOH, producing 3 as a yellowish solid $(0.13 \mathrm{~g}), 46 \%$ yield, mp 75-77 ${ }^{\circ} \mathrm{C} .{ }^{1} \mathrm{H}-\mathrm{NMR} \delta 7.02(\mathrm{~d}, J=8.8 \mathrm{~Hz}, 1 \mathrm{H}, \mathrm{H}-5), 7.14-7.17(\mathrm{~m}, 1 \mathrm{H}, \mathrm{Ar}), 7.37-7.44$ $(\mathrm{m}, 3 \mathrm{H}, \mathrm{Ar}), 7.49(\mathrm{dd}, J=2.4$ and $8.8 \mathrm{~Hz}, 1 \mathrm{H}, \mathrm{H}-4), 7.57(\mathrm{~d}, J=15.2 \mathrm{~Hz}, 1 \mathrm{H}, \beta-\mathrm{CH}=), 7.87(\mathrm{~d}, J=2.4 \mathrm{~Hz}$, $1 \mathrm{H}, \mathrm{H}-6), 7.91(\mathrm{~d}, J=15.2 \mathrm{~Hz}, 1 \mathrm{H}, \alpha-\mathrm{CH}=) .{ }^{13} \mathrm{C}-\mathrm{NMR} \delta 113.26,114.45,119.91,123.81,124.28,127.77$, 130.20, 131.86, 136.22, 161.16, 162.58, 192.51. ESI-MS $(m / z) 277(\mathrm{M}+1)$. HRMS ESI + [M + 1]: calcd for $\mathrm{C}_{15} \mathrm{H}_{10} \mathrm{ClFO}_{2}$, 277.0431. Found: 277.0432.

(E)-1-(5-Chloro-2-hydroxyphenyl)-3-(4-fluorophenyl)prop-2-en-1-one (4). Following route A, and starting from $5^{\prime}$-chloro-2'-hydroxyacetophenone $(0.17 \mathrm{~g}, 1.0 \mathrm{mmol})$ and 4 -fluorobenzaldehyde $(0.14 \mathrm{~g}, 1.1 \mathrm{mmol})$, a solid product was obtained that was collected by vacuum filtration and crystallized from $\mathrm{EtOH}$, to obtain 4 as a white solid $(0.21 \mathrm{~g}), 75 \%$ yield, $\mathrm{mp} 79-81{ }^{\circ} \mathrm{C} .{ }^{1} \mathrm{H}-\mathrm{NMR} \delta 6.99(\mathrm{~d}, J=8.8 \mathrm{~Hz}, 1 \mathrm{H}, \mathrm{H}-5)$, $7.13\left(\mathrm{~d}, J=8.8 \mathrm{~Hz}, 1 \mathrm{H}, \mathrm{H}-3^{\prime}\right), 7.15\left(\mathrm{~d}, J=8.8 \mathrm{~Hz}, 1 \mathrm{H}, \mathrm{H}-5^{\prime}\right), 7.45(\mathrm{dd}, J=2.4$ and $8.8 \mathrm{~Hz}, 1 \mathrm{H}, \mathrm{H}-4) 7.49(\mathrm{~d}$, $J=15.2 \mathrm{~Hz}, 1 \mathrm{H}, \beta-\mathrm{CH}=), 7.68\left(\mathrm{~d}, J=8.4 \mathrm{~Hz}, 1 \mathrm{H}, \mathrm{H}-2^{\prime}\right), 7.69\left(\mathrm{~d}, J=8.8 \mathrm{~Hz}, 1 \mathrm{H}, \mathrm{H}-6^{\prime}\right), 7.80(\mathrm{~d}, J=2.4 \mathrm{~Hz}$, $1 \mathrm{H}, \mathrm{H}-6), 7.92(\mathrm{~d}, J=15.2 \mathrm{~Hz}, 1 \mathrm{H}, \alpha-\mathrm{CH}=) .{ }^{13} \mathrm{C}-\mathrm{NMR} \delta 116.25,116.47,119.19,120.29,120.54,123.57$, $128.75,130.85136 .14,145.16,162.08,192.64$. ESI-MS $(m / z) 277(\mathrm{M}+1)$. HRMS ESI + [M + 1]: calcd for $\mathrm{C}_{15} \mathrm{H}_{10} \mathrm{ClFO}_{2}$, 277.0431. Found: 277.0433. 
(E)-1-(5-Chloro-2-hydroxyphenyl)-3-(3,5-difluorophenyl)prop-2-en-1-one (5). Following route A, and starting from 5'-chloro-2'-hydroxyacetophenone $(0.17 \mathrm{~g}, 1.0 \mathrm{mmol})$ and 3,5-di-fluorobenzaldehyde $(0.16 \mathrm{~g}$, $1.1 \mathrm{mmol})$, a solid product was obtained that was collected by vacuum filtration and crystallized from $\mathrm{EtOH}$, to obtain 5 as a white solid $(0.20 \mathrm{~g}), 67 \%$ yield, mp $102-103{ }^{\circ} \mathrm{C} .{ }^{1} \mathrm{H}-\mathrm{NMR} \delta 6.92(\mathrm{t}, J=8.4 \mathrm{~Hz} 1 \mathrm{H}$, $\left.\mathrm{H}-4^{\prime}\right), 7.02(\mathrm{~d}, J=9.2 \mathrm{~Hz}, 1 \mathrm{H}, \mathrm{H}-3), 7.20\left(\mathrm{~d}, J=6.0 \mathrm{~Hz}, 2 \mathrm{H}, \mathrm{H}-2^{\prime}\right.$ and $\left.\mathrm{H}-6^{\prime}\right), 7.48(\mathrm{dd}, J=2.0 \mathrm{and} 8.8 \mathrm{~Hz}$, $1 \mathrm{H}, \mathrm{H}-4), 7.55$ (d, J = 15.6 Hz, 1H, $\beta-\mathrm{CH}=), 7.85$ (s, 1H, H-6), 7.83 (d, J = 15.6 Hz, 1H, $\alpha-\mathrm{CH}=), 12.98$ (br, 1H, OH). ${ }^{13} \mathrm{C}-\mathrm{NMR} \delta 103.25,109.47,119.33,124.29,127.53,130.57,131.75,137.14,138.99,160.68,192.33$. ESI-MS $(m / z) 295(\mathrm{M}+1)$. HRMS ESI + [M + 1]: calcd for $\mathrm{C}_{15} \mathrm{H}_{9} \mathrm{ClF}_{2} \mathrm{O}_{2}$, 295.0337. Found: 295.0339.

(E)-1-(5-chloro-2-hydroxyphenyl)-3-(4-(dimethylamino)phenyl)prop-2-en-1-one (6). Following route B, and starting from $5^{\prime}$-chloro-2'-hydroxyacetophenone $(0.17 \mathrm{~g}, 1.0 \mathrm{mmol})$ and 4 -(dimethylamino)benzaldehyde $(0.16 \mathrm{~g}, 1.1 \mathrm{mmol})$, a crude of reaction was obtained purified by column chromatography (PE/EtOAc 7:3), and crystallized from EtOH to obtain 6 as a red solid $(0.20 \mathrm{~g}), 67 \%$ yield, mp $125-127{ }^{\circ} \mathrm{C}$. ${ }^{1} \mathrm{H}-\mathrm{NMR}$ $\delta 3.10\left(\mathrm{~s}, 6 \mathrm{H}, \mathrm{CH}_{3}\right), 6.79\left(\mathrm{~d}, J=8.4 \mathrm{~Hz}, 2 \mathrm{H}, \mathrm{H}-2^{\prime}\right.$ and $\left.\mathrm{H}-6^{\prime}\right), 6.97(\mathrm{~d}, J=9.2 \mathrm{~Hz}, 1 \mathrm{H}, \mathrm{H}-3), 7.38(\mathrm{~d}$, $J=15.2 \mathrm{~Hz}, 1 \mathrm{H}, \beta-\mathrm{CH}=), 7.41(\mathrm{dd}, J=2.4$ and $8.8 \mathrm{~Hz}, 1 \mathrm{H}, \mathrm{H}-4), 7.62\left(\mathrm{~d}, J=8.4 \mathrm{~Hz}, 2 \mathrm{H}, \mathrm{H}-3^{\prime}\right.$ and $\left.\mathrm{H}-5^{\prime}\right)$, $7.88(\mathrm{~d}, J=2.8 \mathrm{~Hz}, 1 \mathrm{H}, \mathrm{H}-6), 7.95(\mathrm{~d}, J=14.8 \mathrm{~Hz}, 1 \mathrm{H}, \alpha-\mathrm{CH}=), 13.10(\mathrm{br}, 1 \mathrm{H}, \mathrm{OH}) .{ }^{13} \mathrm{C}-\mathrm{NMR} \delta 40.08$, 111.77, 113.41, 120.01, 121.03, 122.05, 123.15, 128.52, 131.14, 135.31, 147.58, 152.54, 161.94. ESI-MS (m/z) $302(\mathrm{M}+1)$. HRMS ESI + [M + 1]: calcd for $\mathrm{C}_{17} \mathrm{H}_{16} \mathrm{ClNO}_{2}, 302.0948$. Found: 302.0950 .

(E)-1-(5-Fluoro-2-hydroxyphenyl)-3-(3-fluorophenyl)prop-2-en-1-one (7). Following route A, and starting from 5'-fluoro-2'-hydroxyacetophenone $(0.15 \mathrm{~g}, 1.0 \mathrm{mmol})$ and 3-fluorobenzaldehyde $(0.14 \mathrm{~g}, 1.1 \mathrm{mmol})$, a solid product was obtained that was collected by vacuum filtration and crystallized from EtOH to obtain 7 as a white solid (0.18 g), 70\% yield, mp 92-94 ${ }^{\circ} \mathrm{C} .{ }^{1} \mathrm{H}-\mathrm{NMR} \delta 7.00-7.04$ (m, 1H, Ar), 7.15-7.19 (m, 1H, Ar), 7.26-7.25 (m, 1H, Ar), 7.37-7.39 (m, 1H, Ar), 7.41-7.45 (m, 2H, Ar), 7.54 (d, J = 15.6 Hz, 1H, $\beta-\mathrm{CH}=), 7.56-7.29(\mathrm{~m}, 1 \mathrm{H}), 7.90(\mathrm{~d}, J=15.2 \mathrm{~Hz}, 1 \mathrm{H}, \alpha-\mathrm{CH}=) .{ }^{13} \mathrm{C}-\mathrm{NMR} \delta 110.22,114.44,118.29,120.29$, $123.44,123.56,125.57,130.45,136.14,145.76,159.11,162.08,192.67$. ESI-MS (m/z) $261(\mathrm{M}+1)$. HRMS $\mathrm{ESI}+[\mathrm{M}+1]$ : calcd for $\mathrm{C}_{15} \mathrm{H}_{10} \mathrm{~F}_{2} \mathrm{O}_{2}, 261.0727$. Found: 261.0725.

(E)-1-(5-Fluoro-2-hydroxyphenyl)-3-(4-fluorophenyl)prop-2-en-1-one (8). Following route A, and starting from 5'-fluoro-2'-hydroxyacetophenone $(0.15 \mathrm{~g}, 1.0 \mathrm{mmol})$ and 4-fluorobenzaldehyde $(0.14 \mathrm{~g}, 1.1 \mathrm{mmol})$, a semisolid product was obtained that was extracted with DCM $(3 \times 30 \mathrm{~mL})$. The unified organic layers were dried over anhydrous $\mathrm{Na}_{2} \mathrm{SO}_{4}$ and evaporated to dryness to give a crude that was purified by column chromatography (PE/EtOAc 95:0.5) and then crystallized from EtOAc/ $n$-hexane, to produce 8 as a white solid $(0.21 \mathrm{~g}), 80 \%$ yield, $\mathrm{mp} 94-96{ }^{\circ} \mathrm{C} .{ }^{1} \mathrm{H}-\mathrm{NMR} \delta 7.02(\mathrm{dd}, \mathrm{J}=8.8$ and $9.6 \mathrm{~Hz}, 1 \mathrm{H}, \mathrm{H}-3), 7.17$ $\left(\mathrm{d}, J=8.4 \mathrm{~Hz}, 1 \mathrm{H}, \mathrm{H}-3^{\prime}\right), 7.18\left(\mathrm{~d}, J=8.4 \mathrm{~Hz}, 1 \mathrm{H}, \mathrm{H}-5^{\prime}\right), 7.23-7.26(\mathrm{~m}, 1 \mathrm{H}, \mathrm{H}-4), 7.48(\mathrm{~d}, J=15.2 \mathrm{~Hz}, 1 \mathrm{H}$, $\beta-\mathrm{CH}=), 7.58(\mathrm{dd}, J=2.4$ and $8.8 \mathrm{~Hz}, 1 \mathrm{H}, \mathrm{H}-6), 7.68\left(\mathrm{~d}, J=8.8 \mathrm{~Hz}, 1 \mathrm{H}, \mathrm{H}-2^{\prime}\right), 7.69(\mathrm{~d}, J=8.4 \mathrm{~Hz}, 1 \mathrm{H}$, H-6 $), 7.92$ (d, J = $15.2 \mathrm{~Hz}, 1 \mathrm{H}, \alpha-\mathrm{CH}=), 12.55$ (s, 1H, OH). ${ }^{13} \mathrm{C}-\mathrm{NMR} \delta$ 116.26, 116.67, 119.21, 120.27, $120.76,123.69,128.69,130.23,136.44,159.90,162.69,192.44$. ESI-MS $(m / z) 261(\mathrm{M}+1)$. HRMS ESI + $[\mathrm{M}+1]$ : calcd for $\mathrm{C}_{15} \mathrm{H}_{10} \mathrm{~F}_{2} \mathrm{O}_{2}, 261.0727$. Found: 261.0728 .

(E)-3-(4-(Dimethylamino)phenyl)-1-(5-fluoro-2-hydroxyphenyl)prop-2-en-1-one (9). Following route B, and starting from 5'-fluoro-2'-hydroxyacetophenone $(0.15 \mathrm{~g}, 1.0 \mathrm{mmol})$ and 4 -(dimethylamino)benzaldehyde $(0.16 \mathrm{~g}, 1.1 \mathrm{mmol})$ a crude of reaction was obtained, purified by column chromatography (PE/EtOAc 7:3), and crystallized from EtOH to obtain 9 as a red solid $(0.14 \mathrm{~g}), 50 \%$ yield, mp $131-135{ }^{\circ} \mathrm{C}$. ${ }^{1} \mathrm{H}-\mathrm{NMR}$ $\delta 3.09\left(\mathrm{~s}, 6 \mathrm{H}, \mathrm{CH}_{3}\right), 6.75\left(\mathrm{~d}, J=9.2 \mathrm{~Hz}, 2 \mathrm{H}, \mathrm{H}-3^{\prime}\right.$ and $\left.\mathrm{H}-5^{\prime}\right), 6.97(\mathrm{dd}, J=8.8$ and $8.8 \mathrm{~Hz}, 1 \mathrm{H}, \mathrm{H}-3), 7.24$ $(\mathrm{dd}, J=7.6$ and $8.8 \mathrm{~Hz}, 1 \mathrm{H}, \mathrm{H}-4), 7.34(\mathrm{~d}, J=15.2 \mathrm{~Hz}, 1 \mathrm{H}, \beta-\mathrm{CH}=), 7.57-7.60\left(\mathrm{~m}, 3 \mathrm{H}, \mathrm{H}-6, \mathrm{H}-3^{\prime}\right.$, and H-5') $7.94(\mathrm{~d}, J=15.2 \mathrm{~Hz}, 1 \mathrm{H}, \alpha-\mathrm{CH}=), 12.89$ (s, 1H, OH). ${ }^{13} \mathrm{C}-\mathrm{NMR} \delta 41.35,110.41,117.55,117.23$, $124.78,125.88,145.21,150.61,159.41,159.95,193.57$. ESI-MS $(m / z) 286(\mathrm{M}+1) . \mathrm{HRMS}$ ESI + [M + 1]: calcd for $\mathrm{C}_{17} \mathrm{H}_{16} \mathrm{FNO}_{2}$, 286.1243. Found: 286.1244.

(E)-3-(4-fluorophenyl)-1-(2-methoxy-4-(prop-2-yn-1-yloxy)phenyl)prop-2-en-1-one (10). Following route A, and starting from $45(0.20 \mathrm{~g}, 1.0 \mathrm{mmol})$ and 4-fluorobenzaldehyde $(0.14 \mathrm{~g}, 1.1 \mathrm{mmol})$, a semisolid product was obtained that was extracted with EtOAc $(3 \times 30 \mathrm{~mL})$. The unified organic layers were 
dried over anhydrous $\mathrm{Na}_{2} \mathrm{SO}_{4}$ and evaporated to dryness to give a crude that was purified by column chromatography (PE/EtOAc 8:2), to produce 10 as a solid (0.29 g), $94 \%$ yield, mp 196-168 ${ }^{\circ} \mathrm{C} .{ }^{1} \mathrm{H}-\mathrm{NMR}$ $\delta 2.58(\mathrm{t}, J=2.4 \mathrm{~Hz}, 1 \mathrm{H}, \mathrm{CH}), 3.92\left(\mathrm{~s}, 3 \mathrm{H}, \mathrm{OCH}_{3}\right), 4.77\left(\mathrm{~d}, J=2.0 \mathrm{~Hz}, 2 \mathrm{H}, \mathrm{OCH}_{2}\right), 6.61(\mathrm{~d}, J=2.0 \mathrm{~Hz}$, $1 \mathrm{H}, \mathrm{H}-3), 6.65(\mathrm{dd}, J=2.4$ and $8.8 \mathrm{~Hz}, 1 \mathrm{H}, \mathrm{H}-5), 7.09\left(\mathrm{~d}, J=8.8 \mathrm{~Hz}, 1 \mathrm{H}, \mathrm{H}-3^{\prime}\right), 7.10(\mathrm{~d}, J=8.8 \mathrm{~Hz}, 1 \mathrm{H}$, $\left.\mathrm{H}-6^{\prime}\right), 7.43(\mathrm{~d}, J=16.0 \mathrm{~Hz}, 1 \mathrm{H}, \beta-\mathrm{CH}=), 7.50-7.59\left(\mathrm{~m}, 2 \mathrm{H}, \mathrm{H}-2^{\prime}\right.$ and $\left.\mathrm{H}-6^{\prime}\right), 7.65(\mathrm{~d}, J=16 \mathrm{~Hz}, 1 \mathrm{H}, \alpha-\mathrm{CH}=)$, $7.76(\mathrm{~d}, J=8.8 \mathrm{~Hz}, 1 \mathrm{H}, \mathrm{H}-6) .{ }^{13} \mathrm{C}-\mathrm{NMR} \delta 56.21,76.54,101.11,107.45,115.88,118.66,123.67,130.11$, 130.54, 131.87, 145.64, 162.46, 163.78, 188.32. ESI-MS (m/z) $311(\mathrm{M}+1)$. HRMS ESI + [M + 1]: calcd for $\mathrm{C}_{19} \mathrm{H}_{15} \mathrm{FO}_{3}, 311.1083$. Found: 311.1085 .

(E)-3-(2,4-dichlorophenyl)-1-(2-methoxy-4-(prop-2-yn-1-yloxy)phenyl)prop-2-en-1-one (11). Following route $\mathrm{A}$, and starting from $45(0.20 \mathrm{~g}, 1.0 \mathrm{mmol})$ and 2,4-dichlorobenzaldehyde $(0.19 \mathrm{~g}, 1.1 \mathrm{mmol})$ a solid product was obtained that was collected by vacuum filtration and crystallized from EtOH to give $\mathbf{1 1}$ as a pale yellow solid $(0.29 \mathrm{~g}), 84 \%$ yield, $\mathrm{mp} 174-75^{\circ} \mathrm{C} .{ }^{1} \mathrm{H}-\mathrm{NMR} \delta 2.59(\mathrm{t}, J=2.4 \mathrm{~Hz}, 1 \mathrm{H}, \mathrm{CH}), 3.92(\mathrm{~s}$, $\left.3 \mathrm{H}, \mathrm{OCH}_{3}\right), 4.78\left(\mathrm{~s}, 2 \mathrm{H}, \mathrm{OCH}_{2}\right), 6.61(\mathrm{~d}, J=2.0 \mathrm{~Hz}, 1 \mathrm{H}, \mathrm{H}-3), 6.66(\mathrm{dd}, J=2.4$ and $8.8 \mathrm{~Hz}, 1 \mathrm{H}, \mathrm{H}-5), 7.28$ $\left(\mathrm{dd}, J=2.2\right.$ and $\left.8.4 \mathrm{~Hz} 1 \mathrm{H}, \mathrm{H}-5^{\prime}\right), 7.45\left(\mathrm{~d}, J=2.2 \mathrm{~Hz}, 1 \mathrm{H}, \mathrm{H}-3^{\prime}\right), 7.47(\mathrm{~d}, J=16.0 \mathrm{~Hz}, 1 \mathrm{H}, \beta-\mathrm{CH}=), 7.64(\mathrm{~d}$, $\left.J=8.8 \mathrm{~Hz}, 1 \mathrm{H}, \mathrm{H}-6^{\prime}\right), 7.79(\mathrm{~d}, J=8.8 \mathrm{~Hz}, 1 \mathrm{H}, \mathrm{H}-6), 7.98(\mathrm{~d}, J=16.0 \mathrm{~Hz}, 1 \mathrm{H}, \alpha-\mathrm{CH}=) .{ }^{13} \mathrm{C}-\mathrm{NMR} \delta 55.81$, 56.71, 76.42, 77.66, 101.10, 107.54, 121.56, 122.47, 124.94, 125.98, 127.15, 129.74, 130.45, 1.3.31, 136.60, 161.74, 167.21, 194.11. ESI-MS (m/z) $361(\mathrm{M}+1)$. HRMS ESI + [M + 1]: calcd for $\mathrm{C}_{19} \mathrm{H}_{14} \mathrm{Cl}_{2} \mathrm{O}_{3}, 361.0398$. Found: 361.0399 .

(E)-3-(4-(dimethylamino)phenyl)-1-(2-methoxy-4-(prop-2-yn-1-yloxy) phenyl)prop-2-en-1-one (15). Following route $\mathrm{B}$, and starting from $45(0.19 \mathrm{~g}, 1.0 \mathrm{mmol}) 4$-(dimethylamino)benzaldehyde $(0.16 \mathrm{~g}, 1.1 \mathrm{mmol}) \mathrm{a}$ crude of reaction was obtained that was purified by column chromatography (PE/EtOAc 7:3), and crystallized from EtOH to obtain 15 as a red solid $(0.20 \mathrm{~g}), 62 \%$ yield, $\mathrm{mp} 137-149{ }^{\circ} \mathrm{C} .{ }^{1} \mathrm{H}-\mathrm{NMR} \delta 2.57$ $(\mathrm{t}, J=2.4 \mathrm{~Hz}, 1 \mathrm{H}, \mathrm{CH}), 3.04\left(\mathrm{~s}, 6 \mathrm{H}, \mathrm{CH}_{3}\right), 3.89\left(\mathrm{~s}, 3 \mathrm{H}, \mathrm{OCH}_{3}\right), 4.76\left(\mathrm{~d}, J=2.4 \mathrm{~Hz}, 2 \mathrm{H}, \mathrm{OCH}_{2}\right), 6.60$ (s, 1H, H-3), $6.63(\mathrm{dd}, J=2.4$ and $10.4 \mathrm{~Hz}, 1 \mathrm{H}, \mathrm{H}-5), 6.69\left(\mathrm{~d}, J=8.8 \mathrm{~Hz}, 2 \mathrm{H}, \mathrm{H}-6^{\prime}\right.$ and $\left.\mathrm{H}-2^{\prime}\right), 7.26(\mathrm{~d}$, $J=15.6 \mathrm{~Hz}, 1 \mathrm{H}, \beta-\mathrm{CH}=), 7.63(\mathrm{~d}, J=15.6 \mathrm{~Hz}, 1 \mathrm{H}, \alpha-\mathrm{CH}=), 7.69(\mathrm{~d}, J=8.8 \mathrm{~Hz}, 1 \mathrm{H}, \mathrm{H}-6) .{ }^{13} \mathrm{C}-\mathrm{NMR}$ $\delta 41.34,56.18,55.21,76.44,78.76,101.38,106,96,111.15,113.24,118.91,123.96,124.99,145.12,152.45$, 163.07, 166.21, 198.10. ESI-MS (m/z) $336(\mathrm{M}+1)$. HRMS ESI + [M+1]: calcd for $\mathrm{C}_{21} \mathrm{H}_{21} \mathrm{NO}_{3}, 336.1599$. Found: 336.1597.

(E)-3-(4-(dimethylamino)phenyl)-1-(2-hydroxy-4-(prop-2-yn-1-yloxy)phenyl)prop-2-en-1-one (17). Following route $\mathrm{B}$, and starting from $42(0.20 \mathrm{~g}, 1.0 \mathrm{mmol}) 4$-(dimethylamino)benzaldehyde $(0.16 \mathrm{~g}, 1.1 \mathrm{mmol})$, a crude of reaction was obtained that was purified by column chromatography (PE/EtOAc 7:3), and crystallized from EtOH to obtain 17 as a red solid $(0.20 \mathrm{~g}), 62 \%$ yield, $\mathrm{mp} 137-149{ }^{\circ} \mathrm{C} .{ }^{1} \mathrm{H}-\mathrm{NMR} \delta 2.59$ $(\mathrm{t}, J=2.4 \mathrm{~Hz}, 1 \mathrm{H}, \mathrm{CH}), 3.92\left(\mathrm{~s}, 3 \mathrm{H}, \mathrm{OCH}_{3}\right), 4.78\left(\mathrm{~s}, 2 \mathrm{H}, \mathrm{OCH}_{2}\right), 6.61(\mathrm{~d}, J=2.0 \mathrm{~Hz}, 1 \mathrm{H}, \mathrm{H}-3), 6.66(\mathrm{dd}$, $J=2.4$ and $8.8 \mathrm{~Hz}, 1 \mathrm{H}, \mathrm{H}-5), 7.28\left(\mathrm{dd}, J=2.2\right.$ and $\left.8.4 \mathrm{~Hz} 1 \mathrm{H}, \mathrm{H}-5^{\prime}\right), 7.45\left(\mathrm{~d}, J=2.2 \mathrm{~Hz}, 1 \mathrm{H}, \mathrm{H}-3^{\prime}\right), 7.47(\mathrm{~d}$, $J=16.0 \mathrm{~Hz}, 1 \mathrm{H}, \beta-\mathrm{CH}=), 7.64\left(\mathrm{~d}, J=8.8 \mathrm{~Hz}, 1 \mathrm{H}, \mathrm{H}-6^{\prime}\right), 7.79(\mathrm{~d}, J=8.8 \mathrm{~Hz}, 1 \mathrm{H}, \mathrm{H}-6), 7.98(\mathrm{~d}, J=16.0 \mathrm{~Hz}$, $1 \mathrm{H}, \alpha-\mathrm{CH}=) .{ }^{13} \mathrm{C}-\mathrm{NMR} \delta 55.81,56.71,76.42,77.66,101.10,107.54,121.56,122.47,124.94,125.98,127.15$, 129.74, 130.45, 1.3.31, 136.60, 161.74, 167.21, 194.11. ESI-MS $(m / z) 322(\mathrm{M}+1)$. HRMS ESI + [M + 1]: calcd for $\mathrm{C}_{20} \mathrm{H}_{19} \mathrm{NO}_{3}, 322.1443$. Found: 322.1445.

(E)-3-(2,4-dichlorophenyl)-1-(2-hydroxy-4-((3-methylbut-2-en-1-yl)oxy)phenyl)prop-2-en-1-one (19). Following route $\mathrm{A}$, and starting from $41(0.22 \mathrm{~g}, 1.0 \mathrm{mmol})$ and 2,4-dichlorobenzaldehyde $(0.19 \mathrm{~g}, 1.1 \mathrm{mmol}) \mathrm{a}$ solid product was obtained that was collected by vacuum filtration and crystallized from EtOH to give 19 as a pale yellow solid $(0.33 \mathrm{~g}), 88 \%$ yield, mp 191-93 ${ }^{\circ} \mathrm{C} .{ }^{1} \mathrm{H}-\mathrm{NMR} \delta 1.77\left(\mathrm{~s}, 3 \mathrm{H}, \mathrm{CH}_{3}\right), 1.83(\mathrm{~s}, 3 \mathrm{H}$, $\left.\mathrm{CH}_{3}\right), 4.59\left(\mathrm{~d}, J=6.8 \mathrm{~Hz}, 2 \mathrm{H}, \mathrm{OCH}_{2}\right), 5.50(\mathrm{t}, J=6.8 \mathrm{~Hz}, 1 \mathrm{H}, \mathrm{CH}), 6.51(\mathrm{~d}, J=7.2 \mathrm{~Hz}, 1 \mathrm{H}, \mathrm{H}-5), 6.52(\mathrm{~s}$, $1 \mathrm{H}, \mathrm{H}-3), 7.32\left(\mathrm{dd}, J=2.2\right.$ and $\left.6.8 \mathrm{~Hz}, 1 \mathrm{H}, \mathrm{H}-5^{\prime}\right), 7.50\left(\mathrm{~d}, J=2.0 \mathrm{~Hz}, 1 \mathrm{H}, \mathrm{H}-3^{\prime}\right), 7.69(\mathrm{~d}, J=8.8 \mathrm{~Hz}, 1 \mathrm{H}$, $\left.\mathrm{H}-6^{\prime}\right), 7.55(\mathrm{~d}, J=15.6 \mathrm{~Hz}, 1 \mathrm{H}, \beta-\mathrm{CH}=), 7.80(\mathrm{~d}, J=9.2 \mathrm{~Hz}, 1 \mathrm{H}, \mathrm{H}-6), 8.19(\mathrm{~d}, J=15.6 \mathrm{~Hz}, 1 \mathrm{H}, \alpha-\mathrm{CH}=)$, 13.3 (s, 1H, OH). ${ }^{13} \mathrm{C}-\mathrm{NMR} \delta 18.23,24.67,64.64,103.12,107.75,113.93,119.45,121.43,124.11,128.31$, 130.00, 131.05, 131. 77, 138.54, 145.46, 165.92, 169.03, 194.34. ESI-MS $(m / z) 377(\mathrm{M}+1)$. HRMS ESI + $[\mathrm{M}+1]$ : calcd for $\mathrm{C}_{20} \mathrm{H}_{18} \mathrm{Cl}_{2} \mathrm{O}_{3}$, 377.0711. Found: 377.0713. 
(E)-1-(2,4-bis(prop-2-yn-1-yloxy)phenyl)-3-(2,4-dichlorophenyl)prop-2-en-1-one (23). Following route A, and starting from $47(0.23 \mathrm{~g}, 1.0 \mathrm{mmol})$ and 2,4-dichlorobenzaldehyde $(0.19 \mathrm{~g}, 1.1 \mathrm{mmol})$ a solid product was obtained that was collected by vacuum filtration and crystallized from EtOH to give 23 as a pale yellow solid $(0.30 \mathrm{~g}), 78 \%$ yield, $\mathrm{mp} 166-68{ }^{\circ} \mathrm{C} .{ }^{1} \mathrm{H}-\mathrm{NMR} \delta 2.58-2.62(\mathrm{~m}, 2 \mathrm{H}, \mathrm{CH}), 4.77(\mathrm{~d}, \mathrm{~J}=2.4 \mathrm{~Hz}$, $\left.2 \mathrm{H}, \mathrm{OCH}_{2}\right), 4.79\left(\mathrm{~d}, J=2.4 \mathrm{~Hz}, 2 \mathrm{H}, \mathrm{OCH}_{2}\right), 6.70(\mathrm{~d}, J=2.0 \mathrm{~Hz}, 1 \mathrm{H}, \mathrm{H}-3), 6.73(\mathrm{dd}, J=2.0$ and $8.0 \mathrm{~Hz}$, $1 \mathrm{H}, \mathrm{H}-5), 7.26\left(\mathrm{dd}, J=2.0\right.$ and $\left.8.0 \mathrm{~Hz}, 1 \mathrm{H}, \mathrm{H}-5^{\prime}\right), 7.45\left(\mathrm{~d}, J=2.0 \mathrm{~Hz}, 1 \mathrm{H}, \mathrm{H}-3^{\prime}\right), 7.54(\mathrm{~d}, J=16.0 \mathrm{~Hz}$, $1 \mathrm{H}, \beta-\mathrm{CH}=), 7.70\left(\mathrm{~d}, J=8.4 \mathrm{~Hz}, 1 \mathrm{H}, \mathrm{H}-6^{\prime}\right), 7.82(\mathrm{~d}, J=8.4 \mathrm{~Hz}, 1 \mathrm{H}, \mathrm{H}-6), 7.99(\mathrm{~d}, J=15.6 \mathrm{~Hz}, 1 \mathrm{H}$, $\alpha-\mathrm{CH}=) .{ }^{13} \mathrm{C}-\mathrm{NMR} \delta 56.44,75.16,78.92,101.33,107.21,130.55,121.98,124.27,126.19,127.54,128.23$, 131.29, 137.37, 148.32, 162.62, 166.88, 193.71. ESI-MS $(m / z) 385(M+1)$. HRMS ESI + [M + 1]: calcd for $\mathrm{C}_{21} \mathrm{H}_{14} \mathrm{Cl}_{2} \mathrm{O}_{3}, 385.0398$. Found: 385.0398.

(E)-1-(2,4-bis(prop-2-yn-1-yloxy)phenyl)-3-(4-(dimethylamino)phenyl)prop-2-en-1-one (27). Following route $\mathrm{B}$, and starting from $47(0.23 \mathrm{~g}, 1.0 \mathrm{mmol})$ and 4-(dimethylamino)benzaldehyde $(0.16 \mathrm{~g}, 1.1 \mathrm{mmol})$, a crude of reaction was obtained that was purified by column chromatography (PE/EtOAc 7:3), and crystallized from EtOH to obtain to obtain 27 as a red solid $(0.19 \mathrm{~g}), 55 \%$ yield, mp $127-129{ }^{\circ} \mathrm{C}$. ${ }^{1} \mathrm{H}-\mathrm{NMR}$ $\delta$ 2.56-2.61 (m, 2H, CH), $3.02\left(\mathrm{~s}, 3 \mathrm{H}, \mathrm{CH}_{3}\right), 3.02\left(\mathrm{~s}, 3 \mathrm{H}, \mathrm{CH}_{3}\right), 4.72-4.78\left(\mathrm{~m}, 4 \mathrm{H}, \mathrm{OCH}_{2}\right), 6.53(\mathrm{dd}, J=2.0$ and $8.4 \mathrm{~Hz}, 1 \mathrm{H}, \mathrm{H}-5), 6.56(\mathrm{~d}, J=2.4 \mathrm{~Hz}, 1 \mathrm{H}, \mathrm{H}-3), 6.7\left(\mathrm{~d}, J=8.4 \mathrm{~Hz}, 2 \mathrm{H}, \mathrm{H}-3^{\prime}\right.$ and H-5'), $7.36(\mathrm{~d}$, $J=15.2 \mathrm{~Hz}, 1 \mathrm{H}, \beta-\mathrm{CH}=), 7.58\left(\mathrm{~d}, J=8.4 \mathrm{~Hz}, 2 \mathrm{H}, \mathrm{H}-2^{\prime}\right.$ and $\left.\mathrm{H}-6^{\prime}\right), 7.87(\mathrm{~d}, J=8.8 \mathrm{~Hz}, 1 \mathrm{H}, \mathrm{H}-6), 7.89(\mathrm{~d}$, $J=15.2 \mathrm{~Hz}, 1 \mathrm{H}, \alpha-\mathrm{CH}=) .{ }^{13} \mathrm{C}-\mathrm{NMR} \delta 41.41,41.49,56.43,56.63,76.11,76.32,78.78,78.92,101.33,107.64$, $111.32,118.32,118.54,123.564,124.32,129.95,131.12,145.63,151.01,162.90,165.17,196.15$. ESI-MS $(m / z)$ $360(\mathrm{M}+1)$. HRMS ESI + [M + 1]: calcd for $\mathrm{C}_{23} \mathrm{H}_{21} \mathrm{NO}_{3}, 360.1599$. Found: 360.1597 .

(E)-3-(4-Fluorophenyl)-1-(2-methoxy-4-(2-(4-phenylpiperazin-1-yl)ethoxy)phenyl)prop-2-en-1-one (28). Following route $\mathrm{A}$, and starting from $48(0.35 \mathrm{~g}, 1.0 \mathrm{mmol})$ and 4-fluorobenzaldehyde $(0.14 \mathrm{~g}, 1.1 \mathrm{mmol})$, a semisolid product was obtained that was extracted with DCM $(3 \times 30 \mathrm{~mL})$. The unified organic layers were dried over anhydrous $\mathrm{Na}_{2} \mathrm{SO}_{4}$ and evaporated to dryness to give a crude that was purified by column chromatography (DCM/MeOH 95:5), to produce 28 as a semisolid product (0.15 g), 32\% yield, that was converted into the hydrochloride salt, mp $174-176{ }^{\circ} \mathrm{C} .{ }^{1} \mathrm{H}-\mathrm{NMR} \delta 3.41-3.45(\mathrm{~m}, 2 \mathrm{H}$, piperazine), 3.61-3.45 (m, 2H, piperazine), 3.91-3.95 (m, 4H, piperazine), $3.96\left(\mathrm{~s}, 3 \mathrm{H}, \mathrm{OCH}_{3}\right), 4.19$ $\left(\mathrm{t}, J=5.6 \mathrm{~Hz}, 2 \mathrm{H}, \mathrm{OCH}_{2}\right), 4.89\left(\mathrm{t}, J=5.6 \mathrm{~Hz}, 2 \mathrm{H}, \mathrm{NCH}_{2}\right), 6.55(\mathrm{dd}, J=8.4$ and $2.2 \mathrm{~Hz}, 1 \mathrm{H}, \mathrm{H}-5), 6.62$ $(\mathrm{d}, J=2.2 \mathrm{~Hz}, 1 \mathrm{H}, \mathrm{H}-3), 6.94-7.06(\mathrm{~m}, 1 \mathrm{H}, \mathrm{Ph}), 7.06-7.11(\mathrm{~m}, 2 \mathrm{H}, \mathrm{Ph}), 7.34-7.38(\mathrm{~m}, 2 \mathrm{H}, \mathrm{Ph}), 7.36(\mathrm{~d}$, $J=15.6 \mathrm{~Hz}, 1 \mathrm{H}, \beta-\mathrm{CH}=), 7.52-7.56\left(\mathrm{~m}, 2 \mathrm{H}, \mathrm{H}-2^{\prime}\right.$ and $\left.\mathrm{H}_{-} 6^{\prime}\right), 7.61(\mathrm{~d}, J=15.6 \mathrm{~Hz}, 1 \mathrm{H}, \alpha-\mathrm{CH}=), 7.69(\mathrm{~d}$, $J=8.8 \mathrm{~Hz}, 1 \mathrm{H}, \mathrm{H}-6) .{ }^{13} \mathrm{C}-\mathrm{NMR} \delta 49.27,53.81,57.03,58.47,66.49,101.67,108.12,114.19,116.25,116.47$, $119.94,128.75,129.26,130.80,136.24,132.45,145.16,151.40,165.36$. ESI-MS $(m / z) 461(M+1)$. HRMS $\mathrm{ESI}+[\mathrm{M}+1]$ : calcd for $\mathrm{C}_{28} \mathrm{H}_{29} \mathrm{FN}_{2} \mathrm{O}_{3}, 461.2240$. Found: 461.2142.

(E)-3-(4-Fluorophenyl)-1-(4-hydroxy-2-methoxyphenyl)prop-2-en-1-one (29). Following route A, and starting from 1-(4-hydroxy-2-methoxyphenyl)ethan-1-one $(0.17 \mathrm{~g}, 1.0 \mathrm{mmol})$ and 4-fluorobenzaldehyde (0.14 g, $1.1 \mathrm{mmol})$, a semisolid product was obtained that was extracted with EtOAc $(3 \times 30 \mathrm{~mL})$. The unified organic layers were dried over anhydrous $\mathrm{Na}_{2} \mathrm{SO}_{4}$ and evaporated to dryness to give a crude that was purified by column chromatography (PE/EtOAc 9:1), and crystallized from EtOH to produce 29 as a solid (0.035 g), 13\% yield, mp 166-168 ${ }^{\circ} \mathrm{C} .{ }^{1} \mathrm{H}-\mathrm{NMR} \delta 3.89\left(\mathrm{~s}, 3 \mathrm{H}, \mathrm{OCH}_{3}\right) .6 .50(\mathrm{dd}, J=2.2$ and $8.4 \mathrm{~Hz}$, $1 \mathrm{H}, \mathrm{H}-5), 6.51(\mathrm{~d}, J=2.2 \mathrm{~Hz}, 1 \mathrm{H}, \mathrm{H}-3), 7.06-7.10\left(\mathrm{~m}, 2 \mathrm{H}, \mathrm{H}-3^{\prime}\right.$ and $\left.\mathrm{H}-5^{\prime}\right), 7.44(\mathrm{~d}, J=16.0 \mathrm{~Hz}, 1 \mathrm{H}, \beta-\mathrm{CH}=)$, 7.55-7.58 (m, 2H, H-2' and H-6 $\left.{ }^{\prime}\right), 7.61(\mathrm{~d}, J=16.0 \mathrm{~Hz}, 1 \mathrm{H}, \beta-\mathrm{CH}=), 764(\mathrm{~d}, J=15.6 \mathrm{~Hz}, 1 \mathrm{H}, \alpha-\mathrm{CH}=), 7.69$ $(\mathrm{d}, J=8.8 \mathrm{~Hz}, 1 \mathrm{H}, \mathrm{H}-6) .{ }^{13} \mathrm{C}-\mathrm{NMR} \delta 102.64,113.45,115.24,115.28,118.67,130.25,130.56,145.21,162.49$, 162.77, 165.45, 168.88. ESI-MS (m/z) $273(\mathrm{M}+1)$. HRMS ESI + [M + 1]: calcd for $\mathrm{C}_{16} \mathrm{H}_{13} \mathrm{FO}_{3}, 273.0927$. Found: 273.0925.

(E)-3-(4-fluorophenyl)-1-(4-((1-(2-hydroxyethyl)-1H-1,2,3-triazol-4-yl)methoxy)-2-methoxyphenyl)prop-2-en-1-one (30). Following route A, and starting from $49(0.29 \mathrm{~g}, 1.0 \mathrm{mmol})$ and 4-fluorobenzaldehyde $(0.14 \mathrm{~g}$, $1.1 \mathrm{mmol})$, a solid product was obtained that was collected by vacuum filtration and purified by column chromatography (PE/EtOAc 1:1), to produce 30 as a white solid (0.079 g), 20\% yield, mp 
100-102 ${ }^{\circ} \mathrm{C} .{ }^{1} \mathrm{H}-\mathrm{NMR} \delta 2.93(\mathrm{br}, 1 \mathrm{H}, \mathrm{OH}), 3.88\left(\mathrm{~s}, 3 \mathrm{H}, \mathrm{OCH}_{3}\right), 4.10\left(\mathrm{t}, J=5.2 \mathrm{~Hz}, 2 \mathrm{H}, \mathrm{NCH}_{2}\right), 4.55$ $\left(\mathrm{t}, J=5.2 \mathrm{~Hz}, 2 \mathrm{H}, \mathrm{CH}_{2} \mathrm{OH}\right), 5.21\left(\mathrm{~s}, 2 \mathrm{H}, \mathrm{OCH}_{2}\right), 6.52(\mathrm{~d}, J=2.4 \mathrm{~Hz}, 1 \mathrm{H}, \mathrm{H}-3), 6.62(\mathrm{dd}, J=2.4$ and $7.6 \mathrm{~Hz}$, $1 \mathrm{H}, \mathrm{H}-5), 7.42-7.49\left(\mathrm{~m}, 2 \mathrm{H}, \mathrm{H}-3^{\prime}\right.$ and $\left.\mathrm{H}-5^{\prime}\right), 7.60(\mathrm{~d}, J=15.6 \mathrm{~Hz}, 1 \mathrm{H}, \beta-\mathrm{CH}=), 7.63-7.69\left(\mathrm{~m}, 2 \mathrm{H}, \mathrm{H}-2^{\prime}\right.$ and $\left.\mathrm{H}-6^{\prime}\right), 7.80(\mathrm{~s}, 1 \mathrm{H}$, triazole $\mathrm{CH}), 7.74(\mathrm{~d}, J=15.6 \mathrm{~Hz}, 1 \mathrm{H}, \alpha-\mathrm{CH}=),(7.83(\mathrm{~d}, J=8.0 \mathrm{~Hz}, 1 \mathrm{H}, \mathrm{H}-6)$. ${ }^{13}$ C-NMR $\delta 54.11,55.64,60.57,72.12,100.54,105.21,115.64,115.74,118.52,123.77,127.32,130.47,131.25$, 131.55, 142.84, 145.37, 145.22, 162.34, 167.88, 195.94. ESI-MS $(\mathrm{m} / \mathrm{z}) 398(\mathrm{M}+1)$. HRMS ESI + [M + 1]: calcd for $\mathrm{C}_{21} \mathrm{H}_{20} \mathrm{FN}_{3} \mathrm{O}_{4}, 398.1516$. Found: 398.1515 .

(E)-3-(4-fluorophenyl)-1-(4-(2-hydroxyethoxy)phenyl)prop-2-en-1-one (31). Following route A, and starting from $50(0.18 \mathrm{~g}, 1.0 \mathrm{mmol})$ and 4-fluorobenzaldehyde $(0.14 \mathrm{~g}, 1.1 \mathrm{mmol})$, a solid product was obtained that was collected by vacuum filtration and purified by column chromatography (PE/EtOAc 4:1), to produce 31 as a white solid $(0.19 \mathrm{~g}), 67 \%$ yield. ${ }^{1} \mathrm{H}-\mathrm{NMR}$ (acetone $\left.\mathrm{d}_{6}\right) \delta 3.92-3.96\left(\mathrm{~m}, 2 \mathrm{H}, \mathrm{CH}_{2} \mathrm{OH}\right)$, 4.02-4.04 (m, 1H, OH), $4.18\left(\mathrm{t}, J=6.4 \mathrm{~Hz}, 2 \mathrm{H}, \mathrm{CH}_{2} \mathrm{O}\right), 7.05(\mathrm{~d}, J=6.8 \mathrm{~Hz}, 2 \mathrm{H}, \mathrm{H}-3$ and H-5), $7.20(\mathrm{t}$, $J=8.8 \mathrm{~Hz}, 2 \mathrm{H}, \mathrm{H}-3^{\prime}$ and $\left.\mathrm{H}-5^{\prime}\right), 7.72(\mathrm{~d}, J=15.6 \mathrm{~Hz}, 1 \mathrm{H}, \beta-\mathrm{CH}=), 7.81(\mathrm{~d}, J=15.6 \mathrm{~Hz}, 1 \mathrm{H}, \alpha-\mathrm{CH}=)$, 7.83-7.88 (m, 2H, H-2 ${ }^{\prime}$ and $\left.\mathrm{H}-6^{\prime}\right), 8.12(\mathrm{~d}, J=6.8 \mathrm{~Hz}, 2 \mathrm{H}, \mathrm{H}-2$ and $\mathrm{H}-6) .{ }^{13} \mathrm{C}-\mathrm{NMR} \delta$ (acetone $\left.\mathrm{d}_{6}\right)$ 60.9, $69.9,114.12,116.80,120.54,129.65,130.22,130.97,131.15,131.45,145.16,160.21,168.01$. ESI-MS (m/z) $287(\mathrm{M}+1)$. HRMS ESI + [M + 1]: calcd for $\mathrm{C}_{17} \mathrm{H}_{15} \mathrm{FO}_{3}, 287.1083$. Found: 287.1085.

(E)-1-(4-((3-methylbut-2-en-1-yl)oxy)phenyl)-3-(pyridin-3-yl)prop-2-en-1-one (32). Following Route C, and starting from $51(0.20 \mathrm{~g}, 1.0 \mathrm{mmol})$ and pyridine-3-carboxyaldehyde $(0.12 \mathrm{~g}, 1.1 \mathrm{mmol})$ a solid product was obtained that was collected by vacuum filtration and crystallized from $\mathrm{EtOH}$ to give $32(0.17 \mathrm{~g})$, $60 \%$ yield, mp 87-88 ${ }^{\circ} \mathrm{C} .{ }^{1} \mathrm{H}-\mathrm{NMR} \delta 1.78\left(\mathrm{~s}, 3 \mathrm{H}, \mathrm{CH}_{3}\right), 1.83\left(\mathrm{~s}, 3 \mathrm{H}, \mathrm{CH}_{3}\right), 4.62\left(\mathrm{~d}, \mathrm{~J}=6.8 \mathrm{~Hz}, 2 \mathrm{H}, \mathrm{OCH}_{2}\right)$, $5.11(\mathrm{t}, J=1.2 \mathrm{~Hz}, 1 \mathrm{H}, \mathrm{CH}), 7.01(\mathrm{~d}, J=8.8 \mathrm{~Hz}, 2 \mathrm{H}, \mathrm{H}-3$ and H-5), 7.35-7.39 (m, 1H, H-5'), $7.62(\mathrm{~d}$, $J=15.6 \mathrm{~Hz}, 1 \mathrm{H}, \beta-\mathrm{CH}=), 7.79(\mathrm{~d}, J=15.6 \mathrm{~Hz}, 1 \mathrm{H}, \alpha-\mathrm{CH}=), 7.95\left(\mathrm{dd}, J=1.6\right.$ and $\left.7.6 \mathrm{~Hz}, 1 \mathrm{H}, \mathrm{H}-4^{\prime}\right), 8.05$ $\left(\mathrm{d}, J=8.8 \mathrm{~Hz}, 2 \mathrm{H}, \mathrm{H}-2\right.$ and H-6), $8.63\left(\mathrm{dd}, J=1.6\right.$ and $\left.7.6 \mathrm{~Hz}, 1 \mathrm{H}, \mathrm{H}-4^{\prime}\right), 8.87\left(\mathrm{~d}, J=2.0 \mathrm{~Hz}, 1 \mathrm{H}, \mathrm{H}-2^{\prime}\right)$. ${ }^{13}$ C-NMR $\delta 54.21,55.87,60.02,72.15,101.33,105.74,113.11,118.21,123.44,128.64,130.21,130.31,130.56$, 131.64, 142.85, 162.18, 162.47. 163.54, 167.04, 195.32. ESI-MS ( $m / z) 294(\mathrm{M}+1)$. HRMS ESI + [M + 1]: calcd for $\mathrm{C}_{19} \mathrm{H}_{19} \mathrm{NO}_{2}$, 294.1494. Found: 294.1495.

(E)-1-(4-((3-methylbut-2-en-1-yl)oxy)phenyl)-3-(pyridin-4-yl)prop-2-en-1-one (33). Following Route C, and starting from $51(0.20 \mathrm{~g}, 1.0 \mathrm{mmol})$ and pyridine-4-carboxyaldehyde $(0.12 \mathrm{~g}, 1.1 \mathrm{mmol})$ a solid was obtained that was filtered under vacuum and crystallized from $\mathrm{EtOH}$ to give $33(0.21 \mathrm{~g}), 77 \%$ yield, mp 91-93 ${ }^{\circ} \mathrm{C} .{ }^{1} \mathrm{H}-\mathrm{NMR} \delta 1.78\left(\mathrm{~s}, 3 \mathrm{H}, \mathrm{CH}_{3}\right), 1.83\left(\mathrm{~s}, 3 \mathrm{H}, \mathrm{CH}_{3}\right), 4.62\left(\mathrm{~d}, J=7.2 \mathrm{~Hz}, 2 \mathrm{H}, \mathrm{OCH}_{2}\right), 5.51(\mathrm{t}$, $J=6.8 \mathrm{~Hz}, 1 \mathrm{H}, \mathrm{CH}), 7.01(\mathrm{~d}, J=8.8 \mathrm{~Hz}, 2 \mathrm{H}, \mathrm{H}-3$ and $\mathrm{H}-5), 7.48\left(\mathrm{~d}, J=7.2 \mathrm{~Hz}, 2 \mathrm{H}, \mathrm{H}-2^{\prime}\right.$ and $\left.\mathrm{H}-6^{\prime}\right), 7.63$ $(\mathrm{d}, J=15.6 \mathrm{~Hz}, 1 \mathrm{H}, \beta-\mathrm{CH}=), 7.71(\mathrm{~d}, J=15.6 \mathrm{~Hz}, 1 \mathrm{H}, \alpha-\mathrm{CH}=), 8.04(\mathrm{~d}, J=8.4 \mathrm{~Hz}, 2 \mathrm{H}, \mathrm{H}-2$ and H-6), 8.69 (d, $J=7.2 \mathrm{~Hz}, 2 \mathrm{H}, \mathrm{H}-3^{\prime}$ and H-5'). ${ }^{13} \mathrm{C}-\mathrm{NMR} \delta 18.32,18.57,21.41,64.21,114.22,119.65,123.74,127.88$, 130.51, 138.08, 144.00, 149.16, 164.77, 191.66. ESI-MS $(m / z) 294(\mathrm{M}+1)$. HRMS ESI + [M + 1]: calcd for $\mathrm{C}_{19} \mathrm{H}_{19} \mathrm{NO}_{2}$, 294.1494. Found: 294.1492.

(E)-1-(4-((3-methylbut-2-en-1-yl)oxy)phenyl)-3-(4-nitrophenyl)prop-2-en-1-one (34). Following Route $\mathrm{C}$ and starting from $51(0.20 \mathrm{~g}, 1.0 \mathrm{mmol})$ and of 4-nitrobenzaldheyde $(0.17 \mathrm{~g} ; 1.1 \mathrm{mmol})$ a solid was obtained that was filtered under vacuum and purified by crystallization from $\mathrm{EtOH}$ to give 34 as a brown powder, $(0.26 \mathrm{~g}) 70 \%$ yield, mp 100-102 ${ }^{\circ} \mathrm{C} .{ }^{1} \mathrm{H}-\mathrm{NMR} \delta 1.79\left(\mathrm{~s}, 3 \mathrm{H}, \mathrm{CH}_{3}\right), 1.85\left(\mathrm{~s}, 3 \mathrm{H}, \mathrm{CH}_{3}\right), 4.62(\mathrm{~d}$, $\left.J=7.2 \mathrm{~Hz}, 2 \mathrm{H}, \mathrm{OCH}_{2}\right), 5.51(\mathrm{t}, J=6.8 \mathrm{~Hz}, 1 \mathrm{H}, \mathrm{CH}), 7.00(\mathrm{~d}, J=8.4 \mathrm{~Hz}, 2 \mathrm{H}, \mathrm{H}-3$ and H-5), $7.63(\mathrm{~d}$, $J=15.6 \mathrm{~Hz}, 1 \mathrm{H}, \beta-\mathrm{CH}=), 7.79\left(\mathrm{~d}, J=8.0 \mathrm{~Hz}, 2 \mathrm{H}, \mathrm{H}-2^{\prime}\right.$ and $\left.\mathrm{H}-6^{\prime}\right),(\mathrm{d}, J=15.6 \mathrm{~Hz}, 1 \mathrm{H}, \beta-\mathrm{CH}=), 7.90(\mathrm{~d}$, $J=15.6 \mathrm{~Hz}, 1 \mathrm{H}, \alpha-\mathrm{CH}=), 8.07(\mathrm{~d}, J=9.2 \mathrm{~Hz}, 2 \mathrm{H}, \mathrm{H}-2$ and $\mathrm{H}-6), 8.29\left(\mathrm{~d}, J=8.8 \mathrm{~Hz}, 2 \mathrm{H}, \mathrm{H}-3^{\prime}\right.$ and $\left.\mathrm{H}-5^{\prime}\right)$. ${ }^{13}$ C-NMR $\delta 18.52,24.11,64.08,114.63,119.08,121.08,123.87,129.45,129.95,138.11,145.36,163.21,189.32$. ESI-MS $(m / z) 338(\mathrm{M}+1)$. HRMS ESI + [M + 1]: calcd for $\mathrm{C}_{20} \mathrm{H}_{19} \mathrm{NO}_{4}$, 338.1392. Found: 338.1394.

(E)-3-(4-(dimethylamino)phenyl)-1-(4-((3-methylbut-2-en-1-yl)oxy)phenyl)prop-2-en-1-one (35). Following Route $\mathrm{B}$, and starting from $51(0.20 \mathrm{~g}, 1.0 \mathrm{mmol})$ and 4 -(dimethylamino)benzaldehyde $(0.16 \mathrm{~g}, 1.1 \mathrm{mmol})$, a red solid was obtained that was filtered under vacuum and crystallized from $\mathrm{EtOH}$ to give 35 as a red powder (0.03 g), $15 \%$ yield, $121-123{ }^{\circ} \mathrm{C} .{ }^{1} \mathrm{H}-\mathrm{NMR} \delta 1.77\left(\mathrm{~s}, 3 \mathrm{H}, \mathrm{CH}_{3}\right), 1.82\left(\mathrm{~s}, 3 \mathrm{H}, \mathrm{CH}_{3}\right), 3.05(\mathrm{~s}, 6 \mathrm{H}$, 
$\left.\mathrm{NCH}_{3}\right), 4.60\left(\mathrm{~d}, J=6.4 \mathrm{~Hz}, 2 \mathrm{H}, \mathrm{OCH}_{2}\right), 5.51(\mathrm{t}, J=6.8 \mathrm{~Hz}, 1 \mathrm{H}, \mathrm{CH}), 6.70\left(\mathrm{~d}, J=8.4 \mathrm{~Hz}, 2 \mathrm{H}, \mathrm{H}-2^{\prime}\right.$ and H- $\left.6^{\prime}\right), 6.98(\mathrm{~d}, J=8.8 \mathrm{~Hz}, 2 \mathrm{H}, \mathrm{H}-3$ and $\mathrm{H}-5), 7.36(\mathrm{~d}, J=15.6 \mathrm{~Hz}, 1 \mathrm{H}, \beta-\mathrm{CH}=), 7.55(\mathrm{~d}, J=9.2 \mathrm{~Hz}, 2 \mathrm{H}$, $\mathrm{H}-3^{\prime}$ and $\left.\mathrm{H}-5^{\prime}\right), 7.79(\mathrm{~d}, J=15.6 \mathrm{~Hz}, 1 \mathrm{H}, \alpha-\mathrm{CH}=), 8.02(\mathrm{~d}, J=8.8 \mathrm{~Hz}, 2 \mathrm{H}, \mathrm{H}-2$ and $\mathrm{H}-6) .{ }^{13} \mathrm{C}-\mathrm{NMR} \delta 18.8$, 24.36, 41.35, 64.02, 11.33, 111.45, 111.66, 114.25, 119.57, 121.18, 124.61, 129.72, 130.12, 130.97, 131.25, 145.74, 150.01, 163.75, 189.22. ESI-MS $(\mathrm{m} / \mathrm{z}) 336(\mathrm{M}+1)$. HRMS ESI + [M + 1]: calcd for $\mathrm{C}_{22} \mathrm{H}_{25} \mathrm{NO}_{2}$, 336.1963. Found: 336.1964.

(E)-1-(4-(prop-2-yn-1-yloxy)phenyl)-3-(pyridin-3-yl)prop-2-en-1-one (36). Following Route C, and starting from $52(0.17 \mathrm{~g}, 1.0 \mathrm{mmol})$ and pyridine-3-carboxyaldehyde $(0.12 \mathrm{~g}, 1.1 \mathrm{mmol})$ a solid was obtained that was filtered under vacuum and crystallized from $\mathrm{EtOH}$ to give $36(0.17 \mathrm{~g}), 67 \%$ yield, $\mathrm{mp} 96-98^{\circ} \mathrm{C}$. ${ }^{1} \mathrm{H}-\mathrm{NMR} \delta 2.58(\mathrm{~d}, J=2.0 \mathrm{~Hz}, 1 \mathrm{H}, \mathrm{CH}), 4.82\left(\mathrm{~d}, J=2.4 \mathrm{~Hz}, 2 \mathrm{H}, \mathrm{OCH}_{2}\right), 7.09(\mathrm{~d}, J=9.2 \mathrm{~Hz}, 2 \mathrm{H}, \mathrm{H}-3$ and H-5), 7.33-7.39 (m, 1H, H-5'), $7.61(\mathrm{~d}, J=16.0 \mathrm{~Hz}, 1 \mathrm{H}, \beta-\mathrm{CH}=), 7.80(\mathrm{~d}, J=15.6 \mathrm{~Hz}, 1 \mathrm{H}, \alpha-\mathrm{CH}=), 7.93$ $\left(\mathrm{dd}, J=1.6\right.$ and $\left.8.8 \mathrm{~Hz}, 1 \mathrm{H}, \mathrm{H}-4^{\prime}\right), 8.07(\mathrm{~d}, J=8.8 \mathrm{~Hz}, 2 \mathrm{H}, \mathrm{H}-2$ and $\mathrm{H}-6), 8.64(\mathrm{dd}, J=1.6$ and $8.8 \mathrm{~Hz}$, $\left.1 \mathrm{H}, \mathrm{H}-3^{\prime}\right), 8.87\left(\mathrm{~d}, J=1.6 \mathrm{~Hz}, 1 \mathrm{H}, \mathrm{H}-2^{\prime}\right) .{ }^{13} \mathrm{C}-\mathrm{NMR} \delta 56.98,76.11,87.91,114.22,114.65,123.45 .123 .87$, $129.64,130.45,130.76,132.16,141.74,142.03,149.84,163.25,189.99$. ESI-MS $(m / z) 264(M+1)$. HRMS $\mathrm{ESI}+[\mathrm{M}+1]$ : calcd for $\mathrm{C}_{17} \mathrm{H}_{13} \mathrm{NO}_{2}$, 264.1024. Found: 264.1022.

(E)-1-(4-(prop-2-yn-1-yloxy)phenyl)-3-(pyridin-4-yl)prop-2-en-1-one (37). Following Route C, and starting from $52(0.17 \mathrm{~g}, 1.0 \mathrm{mmol})$ and pyridine-4-carboxyaldehyde $(0.12 \mathrm{~g}, 1.1 \mathrm{mmol})$ a solid was obtained that was filtered under vacuum and crystallized from EtOH to give $37(0.20 \mathrm{~g}), 80 \%$ yield, $\mathrm{mp} 99-101{ }^{\circ} \mathrm{C}$. ${ }^{1} \mathrm{H}-\mathrm{NMR} \delta 2.57(\mathrm{t}, J=2.0 \mathrm{~Hz}, 1 \mathrm{H}, \mathrm{CH}), 4.79\left(\mathrm{~d}, J=2.4 \mathrm{~Hz}, 2 \mathrm{H}, \mathrm{OCH}_{2}\right), 7.09(\mathrm{~d}, J=9.2 \mathrm{~Hz}, 2 \mathrm{H}, \mathrm{H}-3$ and $\mathrm{H}-5), 7.47\left(\mathrm{~d}, J=8.0 \mathrm{~Hz}, 2 \mathrm{H}, \mathrm{H}-2^{\prime}\right.$ and $\left.\mathrm{H}^{-} 6^{\prime}\right), 7.66(\mathrm{~d}, J=16.4 \mathrm{~Hz}, 1 \mathrm{H}, \beta-\mathrm{CH}=), 7.70(\mathrm{~d}, J=16.4 \mathrm{~Hz}, 1 \mathrm{H}$, $\alpha-\mathrm{CH}=), 8.06(\mathrm{~d}, J=8.8 \mathrm{~Hz}, 2 \mathrm{H}, \mathrm{H}-2$ and $\mathrm{H}-6), 8.69\left(\mathrm{~d}, J=8.6 \mathrm{~Hz}, 2 \mathrm{H}, \mathrm{H}-3^{\prime}\right.$ and $\left.\mathrm{H}-5^{\prime}\right) .{ }^{13} \mathrm{C}-\mathrm{NMR} \delta 56.41$, 76.11, 78.78, 114.21, 114.68, 123.54, 123.98, 124.54, 127.88, 128.45, 130.02. 130.64, 131.11, 144.56, 149.00, 149.857, 163.24, 189.69. ESI-MS (m/z) $264(\mathrm{M}+1)$. HRMS ESI + [M + 1]: calcd for $\mathrm{C}_{17} \mathrm{H}_{13} \mathrm{NO}_{2}, 264.1024$. Found: 264.1025 .

(E)-3-(4-nitrophenyl)-1-(4-(prop-2-yn-1-yloxy)phenyl)prop-2-en-1-one (38). Following Route C, and starting from $52(0.17 \mathrm{~g}, 1.0 \mathrm{mmol})$ and 4-nitrobenzaldheyde $(0.17 \mathrm{~g} ; 1.1 \mathrm{mmol})$ a solid was obtained that was filtered under vacuum and crystallized from $\mathrm{EtOH}$ to give 38 as a brown powder, $(0.16 \mathrm{~g}) 54 \%$ yield, mp 103-105 ${ }^{\circ} \mathrm{C} .{ }^{1} \mathrm{H}-\mathrm{NMR} \delta 2.58(\mathrm{~d}, \mathrm{~J}=2.0 \mathrm{~Hz}, 1 \mathrm{H}, \mathrm{CH}), 4.82\left(\mathrm{~d}, \mathrm{~J}=2.4 \mathrm{~Hz}, 2 \mathrm{H}, \mathrm{OCH}_{2}\right), 7.09(\mathrm{~d}$, $J=8.4 \mathrm{~Hz}, 2 \mathrm{H}, \mathrm{H}-3$ and H-5), $7.64(\mathrm{~d}, J=15.6 \mathrm{~Hz}, 1 \mathrm{H}, \beta-\mathrm{CH}=), 7.78\left(\mathrm{~d}, J=8.8 \mathrm{~Hz}, 2 \mathrm{H}, \mathrm{H}-2^{\prime}\right.$ and $\left.\mathrm{H}-6^{\prime}\right)$, $7.80(\mathrm{~d}, J=15.6 \mathrm{~Hz}, 1 \mathrm{H}, \alpha-\mathrm{CH}=), 8.07\left(\mathrm{~d}, 2 \mathrm{H}, \mathrm{H}-3^{\prime}\right.$ and $\left.\mathrm{H}-5^{\prime}\right), 8.87(\mathrm{~s}, 1 \mathrm{H}, \mathrm{H}-2), 8.07(\mathrm{~d}, J=9.2 \mathrm{~Hz}, 2 \mathrm{H}$, $\mathrm{H}-2$ and H-6), $8.28\left(\mathrm{~d}, J=8.8 \mathrm{~Hz}, 2 \mathrm{H}, \mathrm{H}-3^{\prime}\right.$ and H-5'). ${ }^{13} \mathrm{C}-\mathrm{NMR}\left(\mathrm{CDCl}_{3}\right) \delta 56.21,76.54,78.11,114.77$, $121.18,123.87,129.11,130.54,141.07,145.98,147.64,163.74,189.60$. ESI-MS $(m / z) 308(\mathrm{M}+1)$. HRMS ESI $+[\mathrm{M}+1]$ : calcd for $\mathrm{C}_{18} \mathrm{H}_{13} \mathrm{NO}_{4}, 308.0923$. Found: 308.0922.

(E)-3-(4-(dimethylamino)phenyl)-1-(4-(prop-2-yn-1-yloxy)phenyl)prop-2-en-1-one (39). Following Route B, and starting from $52(0.17 \mathrm{~g}, 1.0 \mathrm{mmol})$ and 4 -(dimethylamino)benzaldehyde $(0.16 \mathrm{~g}, 1.1 \mathrm{mmol})$, a red solid was obtained that was filtered under vacuum and crystallized from EtOH to give 39 as a red powder $(0.03 \mathrm{~g}), 15 \%$ yield, $133-135{ }^{\circ} \mathrm{C} .{ }^{1} \mathrm{H}-\mathrm{NMR} \delta 2.56(\mathrm{t}, J=2.4 \mathrm{~Hz}, 1 \mathrm{H}, \mathrm{CH}), 3.05\left(\mathrm{~d}, 6 \mathrm{H}, \mathrm{NCH}_{3}\right)$, $4.82\left(\mathrm{~d}, J=2.8 \mathrm{~Hz}, 2 \mathrm{H}, \mathrm{OCH}_{2}\right), 6.70(\mathrm{~d}, J=8.4 \mathrm{~Hz}, 2 \mathrm{H}, \mathrm{H}-3$ and $\mathrm{H}-5), 7.05\left(\mathrm{~d}, J=9.2 \mathrm{~Hz}, 2 \mathrm{H}, \mathrm{H}-3^{\prime}\right.$ and $\left.\mathrm{H}-5^{\prime}\right), 7.35(\mathrm{~d}, J=15.6 \mathrm{~Hz}, 1 \mathrm{H}, \beta-\mathrm{CH}=), 7.55\left(\mathrm{~d}, J=8.8 \mathrm{~Hz}, 2 \mathrm{H}, \mathrm{H}-2^{\prime}\right.$ and $\left.\mathrm{H}-6^{\prime}\right), 7.80(\mathrm{~d}, J=15.6 \mathrm{~Hz}$, $1 \mathrm{H}, \alpha-\mathrm{CH}=), 8.04(\mathrm{~d}, J=8.8 \mathrm{~Hz}, 2 \mathrm{H}, \mathrm{H}-2$ and $\mathrm{H}-6) .{ }^{13} \mathrm{C}-\mathrm{NMR} \delta 41.12,56.21,76.44,78.64,111.10,114.26$, $121.87,124.68,129.39,129.85,130.22,130.51,145.74,150.63,164.08,189.89$. ESI-MS $(m / z) 306(\mathrm{M}+1)$. HRMS ESI $+[\mathrm{M}+1]$ : calcd for $\mathrm{C}_{20} \mathrm{H}_{19} \mathrm{NO}_{2}, 306.1494$. Found: 306.1492 .

(Z)-6-(prop-2-yn-1-yloxy)-2-(pyridin-3-ylmethylene)benzofuran-3(2H)-one (40). To a solution of $\mathbf{1 6}$ (0.17 g, $0.60 \mathrm{mmol})$ in $\mathrm{EtOH}(17 \mathrm{~mL})$ at $0{ }^{\circ} \mathrm{C}, \mathrm{NaOH}$ aq solution $\left(0.16 \mathrm{~g}, 3.33 \mathrm{mmol}\right.$, dissolved in $1 \mathrm{~mL}$ of $\left.\mathrm{H}_{2} \mathrm{O}\right)$ and $\mathrm{H}_{2} \mathrm{O}_{2}(0.07 \mathrm{~mL}, 3.33 \mathrm{mmol})$ were added dropwise. The reaction was stirred at $\mathrm{rt}$ for $12 \mathrm{~h}$, then water was added and the solution was acidified with $2 \mathrm{~N} \mathrm{HCl}$. The solid formed was separated by vacuum filtration, dried, and purified by column chromatography (EtOAc/MeOH 9:1) to obtain 40 as a red solid $(0.05 \mathrm{~g}), 29 \%$ yield, mp $121.123{ }^{\circ} \mathrm{C} .{ }^{1} \mathrm{H}-\mathrm{NMR} \delta 3.42(\mathrm{t}, J=2.4,1 \mathrm{H}, \mathrm{CH}), 4.69(\mathrm{~d}, J=2.4 \mathrm{~Hz}$, 
$\left.2 \mathrm{H}, \mathrm{OCH}_{2}\right), 6.26(\mathrm{~d}, \mathrm{~J}=8.8 \mathrm{~Hz}, 1 \mathrm{H}, \mathrm{H}-5), 6.28(\mathrm{~s}, 1 \mathrm{H}, \mathrm{H}-7), 7.31-7.34\left(\mathrm{~m}, 1 \mathrm{H}, \mathrm{H}-5^{\prime}\right), 7.59(\mathrm{~d}, J=8.4 \mathrm{~Hz}$, $1 \mathrm{H}, \mathrm{H}-4), 8.12\left(\mathrm{~d}, \mathrm{~J}=8.0 \mathrm{~Hz}, 1 \mathrm{H}, \mathrm{H}-6^{\prime}\right), 8.38(\mathrm{~s}, 1 \mathrm{H}, \mathrm{CH}), 8.46\left(\mathrm{~s}, 1 \mathrm{H}, \mathrm{H}-4^{\prime}\right), 8.91\left(\mathrm{~S}, 1 \mathrm{H}, \mathrm{H}-2^{\prime}\right) .{ }^{13} \mathrm{C}-\mathrm{NMR}$ $\delta 56.21,76.11,78.84,100.00,109.54,112.57,114.08,123.22,125.08,132.11,132.55,132.98,148.64,149.74$, 152.32, 165.09, 167.46, 18.02. ESI-MS $(m / z) 278(\mathrm{M}+1))$. HRMS ESI + [M+1]: calcd for $\mathrm{C}_{17} \mathrm{H}_{11} \mathrm{NO}_{3}$, 278.0817. Found: 278.0815 .

\subsection{Yeast Species and Identification}

The yeasts included in the present study were Candida albicans ATCC 10231 (American Type Culture Collection) and a collection of yeasts recovered from a variety of clinical specimens, i.e., blood, urine, genital swabs, bronchoalveolar lavage, nail specimens, collected at the Microbiology Unit, St. Orsola Malpighi University Hospital, Bologna, Italy. The clinical strain isolates were identified by standard procedures, including colony morphology on chromogenic agar (CHROMagar Candida medium, Becton Dickinson, Heidelberg, Germany) and confirmed by MALDI Biotyper System using matrix-assisted laser desorption ionization-time of flight mass spectrometry (MALDI-TOF MS, Bruker Daltonik, GmbH, Germany) [28]. The distribution of isolates is reported in Tables 1 and 2.

\subsection{In Vitro Susceptibility Testing}

The in vitro antifungal activity of the chalcones was evaluated by a microdilution broth method in accordance with the guidelines provided by the EUCAST Edef 7.3 [22]. Briefly, all strains were cultured on Sabauraud dextrose, then inocula, prepared at 0.5 McFarland, were diluted 1:20 in RPMI-1640 medium (Gibco ${ }^{\circledR}$, ThermoFisher Scientific Inc., Waltham, MA, USA), containing glucose $2 \%, 0.3 \%$ levo-glutamine buffered to $\mathrm{pH} 7.0$ with $0.165 \mathrm{M} 3$-(N-morpholino)propanesulfonic acid (MOPS) to yield $1-5 \times 10^{5}$ cells $/ \mathrm{mL}$. A total of $100 \mu \mathrm{L}$ of the yeast suspension was inoculated in a 96-well microplate and incubated with $100 \mu \mathrm{L}$ of serially 2-fold dilution of the compound in the range 200-6.25 $\mu \mathrm{M}$. The following controls were included: yeast suspensions incubated in RPMI-1640 culture medium (positive growth control), or supplemented with dilutions of DMSO, or fluconazole (Sigma-Aldrich, St. Louis, MO, USA) as a commercial drug. To check the background turbidity of reagents and the sterility of the procedure, dilutions of each compound were incubated in RPMI-1640 culture medium, without yeast inoculum. The inoculated plate was incubated at $37^{\circ} \mathrm{C}$ for $24 \mathrm{~h}$, and subsequently the optical density at $630 \mathrm{~nm}$ was measured by the Multiskan Ascent microplate reader (Thermo Fisher Scientific Inc.). The effectiveness of the compounds was expressed as percent inhibition relative to the positive growth control when the inhibition yielded the $50 \%$ at $100 \mu \mathrm{M}$. The $\mathrm{IC}_{50}$ value was determined by interpolation of the dose-response curves generated by plotting the percentages of growth inhibition, relative to the drug-free control (set to $100 \%$ of growth), as a function of the tested concentrations (on a logarithm scale). Statistical analysis was carried out by the nonlinear regression method using GraphPad Prism version 5.0 for Windows (GraphPad Software, San Diego, CA, USA). All assays were performed in triplicate and at least two independent experiments were carried out.

\subsection{Effect on Yeast-to-Hyphae Transition}

A suspension of $C$. albicans ATCC $10231\left(5 \times 10^{5}\right.$ cells $\left./ \mathrm{mL}\right)$ was prepared in RPMI-1640 culture medium supplemented with 10\% (v/v) FCS (fetal calf serum) and incubated for $2 \mathrm{~h}$ at $37^{\circ} \mathrm{C}$ with chalcones 1, 3-5, 7, 14, and 28 at $\mathrm{IC}_{50}$ values, in a 48-well flat-bottom polystyrene microplate. Blastospore and hyphae forms were observed under a light microscope. Cells from at least two different fields of view were observed and were considered to be germinated if they had a germ tube at least twice the length of the cell diameter [29].

\subsection{Agar-Invasive Hyphal Growth}

For the "Spider" agar assay, a medium consisted in nutrient broth $1 \%(w / v)$, D-mannitol 1\% $(w / v)$, $\mathrm{K}_{2} \mathrm{HPO}_{4} 0.2 \%(w / v)$ and agar $1.35 \%(w / v)$ with the addition of chalcones 1, 3-5, 7, 14, and 28 at $\mathrm{IC}_{50}$ values was used [29]. Aliquots $(2 \mu \mathrm{L})$ of a suspension of C. albicans ATCC $10231\left(5 \times 10^{5}\right.$ cells $\left./ \mathrm{mL}\right)$ were 
spotted onto medium in triplicate and the morphology of growing colonies was observed following three days of incubation at $37^{\circ} \mathrm{C}$. Spider agar plates without chalcones, containing DMSO, served as the control. The presence of filaments at the colony edges was determined using a light microscope under $10 \times$ magnification.

\subsection{Biofilm Investigation}

For biofilm formation, a suspension of C. albicans ATCC 10231 at $5 \times 10^{5}$ cells $/ \mathrm{mL}$ was prepared in RPMI-1640 culture medium and aliquots of $100 \mu \mathrm{L}$ were transferred to a 96-well flat-bottom polystyrene microplate. Cell cultures were treated with $100 \mu \mathrm{L}$ of chalcones 1, 3-5, 7, 14, and 28 at $\mathrm{IC}_{50}$ values, and incubated statically for $24 \mathrm{~h}$ at $37^{\circ} \mathrm{C}$ to allow biofilm formation. Following the attachment phase, the free-floating cells were removed, and biofilms were carefully washed with $200 \mu \mathrm{L}$ of PBS to remove planktonic fungi. The biofilm mass was quantified by crystal violet (CV) staining. Briefly, $200 \mu \mathrm{L}$ of CV solution $(0.1 \%$ in water) were added to each well containing a completely air-dried biofilm, and incubated for $30 \mathrm{~min}$ at $37^{\circ} \mathrm{C}$. Then wells were washed twice with water to remove the unbound dye and CV was dissolved with $200 \mu \mathrm{L}$ of $95 \%$ ethanol for $30 \mathrm{~min}$ [30]. Finally, $150 \mu \mathrm{L}$ of the colored supernatant from each well were transferred to a new microplate and the absorbance was read at $550 \mathrm{~nm}$. The percentage inhibition of biofilm formation for each well containing the compound was calculated by comparing the biofilm mass formed in the absence of test agent. Six wells for each treatment regimen were prepared and the experiment was performed twice. Data were reported as mean OD values \pm standard deviation (SD) and one-way analysis of variance (ANOVA), followed by Dunnett's multiple comparison test to compare data among the different experimental conditions; statistically significant differences were determined at $p<0.05$.

\subsection{Cytotoxicity Tests}

African green monkey kidney cells (Vero ATCC CCL-81) were cultured in Eagle's Minimal Essential Medium (MEM) (Sigma-Aldrich), supplemented with 10\% fetal bovine serum (FBS) (Carlo Erba Reagents, Milan, Italy), $100 \mathrm{U} / \mathrm{mL}$ penicillin, and $100 \mu \mathrm{g} / \mathrm{mL}$ streptomycin at $37{ }^{\circ} \mathrm{C}$ with $5 \% \mathrm{CO}_{2}$. For experiments, cells were seeded into 96-well plates at $10^{4}$ cells/well, and incubated at $37^{\circ} \mathrm{C}$ for $24 \mathrm{~h}$. Following washes with PBS, cell monolayer was incubated with $100 \mu \mathrm{L}$ of serially 2 -fold dilution of the compound in the range 200-6.25 $\mu \mathrm{M}$. Both untreated cells and cells incubated with medium containing solvent dilutions were included in each experiment as controls.

The cell viability was assessed by a WST8-based assay according to the manufacturer's instructions (CCK-8, Cell Counting Kit-8, Dojindo Molecular Technologies, Rockville, MD, USA). After 72 h of incubation, culture medium was removed from each well, the monolayer was washed with PBS, and $100 \mu \mathrm{L}$ of fresh medium containing $10 \mu \mathrm{L}$ of CCK-8 solution were added. Following a $2 \mathrm{~h}$ at $37^{\circ} \mathrm{C}$, the absorbance was measured at 450/630 nm; data were calculated as the percentage of the cell viability relative to the untreated controls.

\section{Conclusions}

In the present study a small library of 40 chalcone-based analogues, differently functionalized on both A-and B-rings, were evaluated in vitro for their antifungal potential. Interestingly, sixteen chalcones showed a good inhibitory activity against $C$. albicans control strain associated with a different degree of cytotoxicity towards mammalian cells. Among them, a subset of seven derivatives (1, 3-5, 7, 14, and 28) exerted a low systemic toxicity, underlying a favorable SI, i.e., degree of host/fungi selectivity. These selective inhibitors were then further investigated regarding their spectrum of activity (collection of Candida spp. and non-Candida spp. isolates obtained from different clinical specimens) and their capability to affect microbial virulence (yeast-to-hyphae transition, filament invasion, and biofilm formation). In particular, derivative $\mathbf{2 8}$ demonstrated a robust dose-response inhibitory effect against all the selected Candida spp. and the clinically relevant non-Candida yeasts, thus emerging as the most relevant antifungal agent of the series. 
On the other hand, compounds 5 and 7, even if associated with a restricted antifungal window, showed great potential for controlling $C$. albicans pathogenesis and virulence due to their capability to interfere with the production of both hyphae and biofilm, perfectly meeting the current paradigm of anti-infective therapeutics. Indeed, these last compounds combine two modes of action by selectively interfering with growth and, as an added value, weakening microbial virulence. Indeed, disarming pathogens rather than killing them is emerging as a novel and effective strategy for infection control.

In summary, this study allowed us to gain insight into the chemical functionalization of the chalcone involved in a favorable antifungal effect. Compounds 5, 7, and 28 could be regarded as valuable lead compounds worth modifying with different approaches, aimed at improving and optimizing the antimicrobial profile.

Supplementary Materials: The following are available online. Table S1. Nonlinear regression parameters of the dose-response curves of chalcone 28 against C. albicans control strain and all Candida spp. clinical isolates; Figure S1. Dose-response curves of chalcone 28 obtained with non-Candida yeasts; Table S2. Nonlinear regression parameters of the dose-response curves of chalcone 28 against non Candida spp. clinical isolates.

Author Contributions: F.B. (Federica Belluti) and F.B. (Francesca Bonvicini) conceived and designed the molecules and the experiments; A.B., F.B. (Francesca Bressan), S.G., and A.R. performed the structural characterization of the synthesized compounds; F.B. (Francesca Bressan) performed the synthesis and the purification of the compounds; F.B. (Federica Belluti) and F.B. (Francesca Bonvicini) wrote the manuscript; A.B., A.R., S.G., and G.A.G. revised the manuscript. All authors read and approved the final manuscript.

Funding: This work was supported by the Fondazione Del Monte di Bologna e Ravenna (Prot. Nr. 349 bis/2016) and by the University of Bologna (RFO funds).

Conflicts of Interest: The authors declare no conflict of interest.

\section{References}

1. Limper, A.H.; Adenis, A.; Le, T.; Harrison, T.S. Fungal infections in HIV/AIDS. Lancet Infect. Dis. 2017, 17, E334-E343. [CrossRef]

2. Brown, G.D.; Denning, D.W.; Gow, N.A.; Levitz, S.M.; Netea, M.G.; White, T.C. Hidden killers: Human fungal infections. Sci. Transl. Med. 2012, 4, 165rv113. [CrossRef] [PubMed]

3. Brown, G.D.; Denning, D.W.; Levitz, S.M. Tackling human fungal infections. Science 2012, 336, 647. [CrossRef]

4. Cavalheiro, M.; Teixeira, M.C. Candida Biofilms: Threats, Challenges, and Promising Strategies. Front. Med. 2018, 5, 28. [CrossRef] [PubMed]

5. Favre, S.; Rougeron, A.; Levoir, L.; Perard, B.; Milpied, N.; Accoceberry, I.; Gabriel, F.; Vigouroux, S. Saprochaete clavata invasive infection in a patient with severe aplastic anemia: Efficacy of voriconazole and liposomal amphotericin B with adjuvant granulocyte transfusions before neutrophil recovery following allogeneic bone marrow transplantation. Med. Mycol. Case Rep. 2016, 11, 21-23. [CrossRef]

6. Duran Graeff, L.; Seidel, D.; Vehreschild, M.J.; Hamprecht, A.; Kindo, A.; Racil, Z.; Demeter, J.; De Hoog, S.; Aurbach, U.; Ziegler, M.; et al. Invasive infections due to Saprochaete and Geotrichum species: Report of 23 cases from the FungiScope Registry. Mycoses 2017, 60, 273-279. [CrossRef] [PubMed]

7. Odds, F.C.; Brown, A.J.; Gow, N.A. Antifungal agents: Mechanisms of action. Trends Microbiol. 2003, 11, 272-279. [CrossRef]

8. Sheng, C.; Zhang, W. New lead structures in antifungal drug discovery. Curr. Med. Chem. 2011, 18, $733-766$. [CrossRef]

9. Hamill, R.J. Amphotericin B formulations: A comparative review of efficacy and toxicity. Drugs 2013, 73, 919-934. [CrossRef]

10. Abreu, A.C.; McBain, A.J.; Simoes, M. Plants as sources of new antimicrobials and resistance-modifying agents. Nat. Prod. Rep. 2012, 29, 1007-1021. [CrossRef]

11. Evans, B.E.; Rittle, K.E.; Bock, M.G.; DiPardo, R.M.; Freidinger, R.M.; Whitter, W.L.; Lundell, G.F.; Veber, D.F.; Anderson, P.S.; Chang, R.S.; et al. Methods for drug discovery: Development of potent, selective, orally effective cholecystokinin antagonists. J. Med. Chem. 1988, 31, 2235-2246. [CrossRef] [PubMed]

12. Di Santo, R. Natural products as antifungal agents against clinically relevant pathogens. Nat. Prod. Rep. 2010, 27, 1084-1098. [CrossRef] [PubMed] 
13. Dimmock, J.R.; Elias, D.W.; Beazely, M.A.; Kandepu, N.M. Bioactivities of chalcones. Curr. Med. Chem. 1999, 6, 1125-1149. [PubMed]

14. Sahu, N.K.; Balbhadra, S.S.; Choudhary, J.; Kohli, D.V. Exploring pharmacological significance of chalcone scaffold: A review. Curr. Med. Chem. 2012, 19, 209-225. [CrossRef] [PubMed]

15. Zhuang, C.; Zhang, W.; Sheng, C.; Zhang, W.; Xing, C.; Miao, Z. Chalcone: A Privileged Structure in Medicinal Chemistry. Chem. Rev. 2017, 117, 7762-7810. [CrossRef] [PubMed]

16. Seleem, D.; Benso, B.; Noguti, J.; Pardi, V.; Murata, R.M. In Vitro and In Vivo Antifungal Activity of Lichochalcone-A against Candida albicans Biofilms. PLoS ONE 2016, 11, e0157188. [CrossRef] [PubMed]

17. Ortalli, M.; Ilari, A.; Colotti, G.; De Ionna, I.; Battista, T.; Bisi, A.; Gobbi, S.; Rampa, A.; Di Martino, R.M.C.; Gentilomi, G.A.; et al. Identification of chalcone-based antileishmanial agents targeting trypanothione reductase. Eur. J. Med. Chem. 2018, 152, 527-541. [CrossRef]

18. Kishbaugh, T.L.S. Pyridines and Imidazopyridines with Medicinal Significance. Curr. Top. Med. Chem. 2016, 16, 3274-3302. [CrossRef]

19. Hagmann, W.K. The many roles for fluorine in medicinal chemistry. J. Med. Chem. 2008, 51, 4359-4369. [CrossRef]

20. Belluti, F.; De Simone, A.; Tarozzi, A.; Bartolini, M.; Djemil, A.; Bisi, A.; Gobbi, S.; Montanari, S.; Cavalli, A.; Andrisano, V.; et al. Fluorinated benzophenone derivatives: Balanced multipotent agents for Alzheimer's disease. Eur. J. Med. Chem. 2014, 78, 157-166. [CrossRef]

21. Rampa, A.; Tarozzi, A.; Mancini, F.; Pruccoli, L.; Di Martino, R.M.; Gobbi, S.; Bisi, A.; De Simone, A.; Palomba, F.; Zaccheroni, N.; et al. Naturally Inspired Molecules as Multifunctional Agents for Alzheimer's Disease Treatment. Molecules 2016, 21, 643. [CrossRef] [PubMed]

22. Arendrup, M.C.; Cuenca-Estrella, M.; Lass-Florl, C.; Hope, W.; Eucast, A. EUCAST technical note on the EUCAST definitive document EDef 7.2: Method for the determination of broth dilution minimum inhibitory concentrations of antifungal agents for yeasts EDef 7.2 (EUCAST-AFST). Clin. Microbiol. Infect. 2012, 18, E246-E247. [CrossRef] [PubMed]

23. Zenger, K.; Dutta, S.; Wolff, H.; Genton, M.G.; Kraus, B. In vitro structure-toxicity relationship of chalcones in human hepatic stellate cells. Toxicology 2015, 336, 26-33. [CrossRef] [PubMed]

24. Cos, P.; Vlietinck, A.J.; Vanden Berghe, D.; Maes, L. Anti-infective potential of natural products: How to develop a stronger in vitro 'proof-of-concept'. J. Ethnopharmacol. 2006, 106, 290-302. [CrossRef] [PubMed]

25. Mahapatra, D.K.; Bharti, S.K.; Asati, V. Chalcone scaffolds as anti-infective agents: Structural and molecular target perspectives. Eur. J. Med. Chem. 2015, 101, 496-524. [CrossRef]

26. Taff, H.T.; Mitchell, K.F.; Edward, J.A.; Andes, D.R. Mechanisms of Candida biofilm drug resistance. Futur. Microbiol. 2013, 8, 1325-1337. [CrossRef]

27. Sardi, J.C.O.; Scorzoni, L.; Bernardi, T.; Fusco-Almeida, A.M.; Giannini, M.J.S.M. Candida species: Current epidemiology, pathogenicity, biofilm formation, natural antifungal products and new therapeutic options. J. Med. Microb. 2013, 62, 10-24. [CrossRef]

28. Bonvicini, F.; Antognoni, F.; Iannello, C.; Maxia, A.; Poli, F.; Gentilomi, G.A. Relevant and selective activity of Pancratium illyricum L. against Candida albicans clinical isolates: A combined effect on yeast growth and virulence. BMC Complement. Altern. Med. 2014, 14, 409. [CrossRef]

29. Sadowska, B.; Budzynska, A.; Stochmal, A.; Zuchowski, J.; Rozalska, B. Novel properties of Hippophae rhamnoides L. twig and leaf extracts - anti-virulence action and synergy with antifungals studied in vitro on Candida spp. model. Microb. Pathog. 2017, 107, 372-379. [CrossRef]

30. Melo, A.S.; Bizerra, F.C.; Freymuller, E.; Arthington-Skaggs, B.A.; Colombo, A.L. Biofilm production and evaluation of antifungal susceptibility amongst clinical Candida spp. isolates, including strains of the Candida parapsilosis complex. Med. Mycol. 2011, 49, 253-262. [CrossRef]

Sample Availability: Samples of the compounds 1-40 are available from the authors. 